\title{
Methods for Controlling Depredation on Piping Plovers in Alberta: A Literature Review and Synthesis
}

RESOURCEDATA AND SPECIES AT RISK SECTION

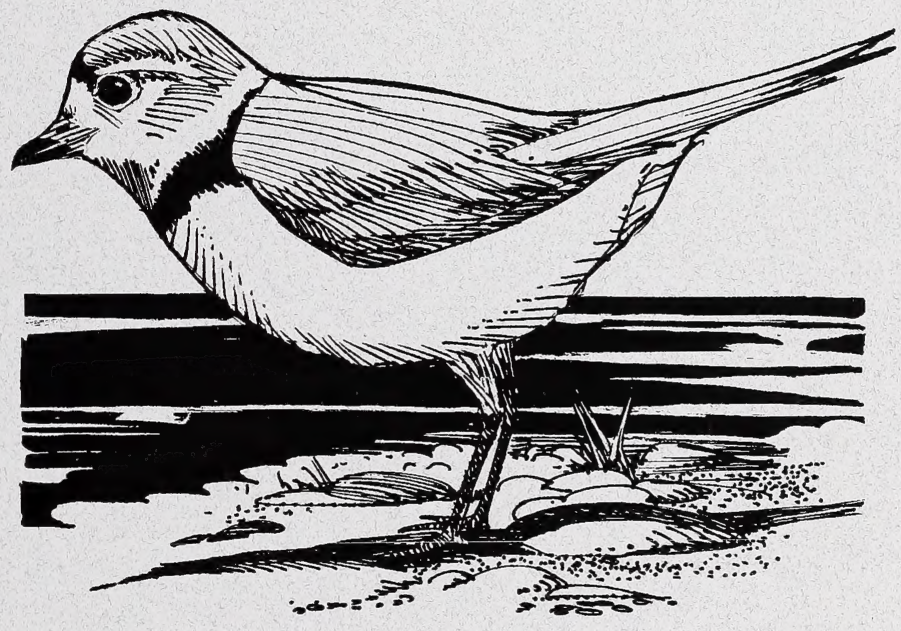

Alberta Species at Risk Report No. 84 
Digitized by the Internet Archive in 2016 


\title{
Methods for Controlling Depredation on Piping Plovers in Alberta: A Literature Review and Synthesis
}

\author{
Roy Schmelzeisen
}

David R.C. Prescott

Lance Engley

Alberta Species at Risk Report No. 84

March 2004

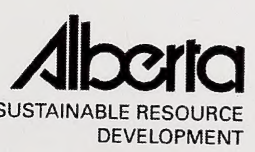

Fish \& Wildlife

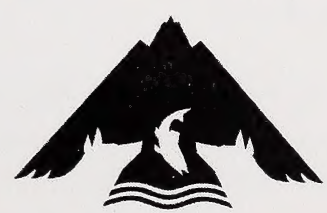

Alberta Conservation Association 
Publication No. I/144

ISBN: 0-7785-2977-0 (Printed Edition)

ISBN: 0-7785-2978-9 (On-line Edition)

ISSN: 1496-7219 (Printed Edition)

ISSN: 1496-7146 (On-line Edition)

Illustration: Brian Huffman

For copies of this report, contact:

Information Centre - Publications

Alberta Environment / Alberta Sustainable Resource Development

Main Floor, Great West Life Building

9920108 Street

Edmonton, Alberta, Canada T5K 2M4

Telephone: (780) 422-2079

OR

Visit our web site at:

http://www3.gov.ab.ca/srd/fw/riskspecies/

This publication may be cited as:

Schmelzeisen, R., D.R.C. Prescott and L. Engley. 2004. Methods for controlling depredation on piping plovers in Alberta: a literature review and synthesis. Alberta Sustainable Resource Development, Fish and Wildlife Division, Alberta Species at Risk Report No. 84, Edmonton, AB. 24 pp. 


\section{TABLE OF CONTENTS}

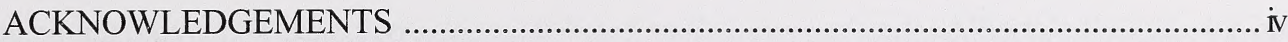

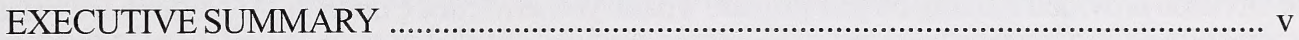

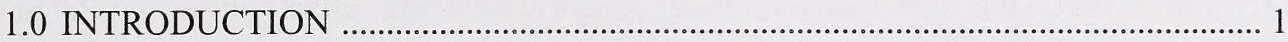

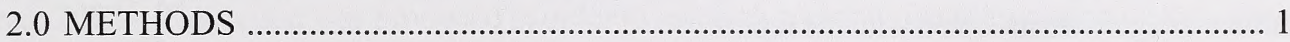

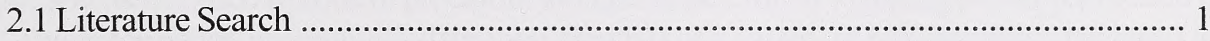

2.2 Identification of Potential Predators ....................................................................... 2

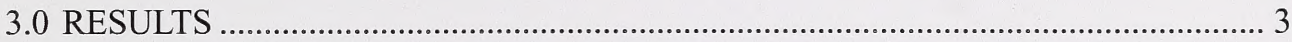

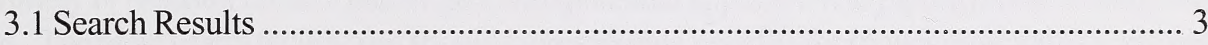

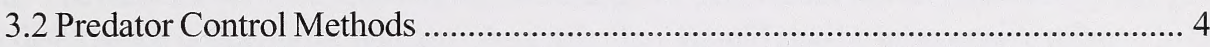

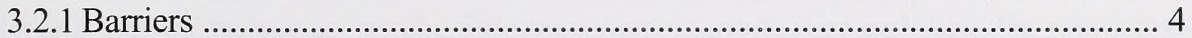

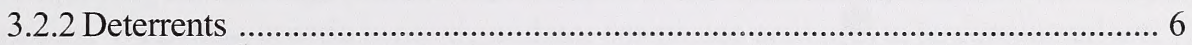

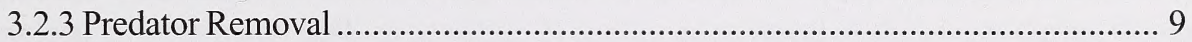

3.2.4 Recruitment Reduction ............................................................................ 10

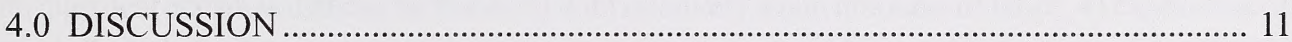

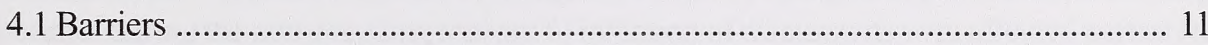

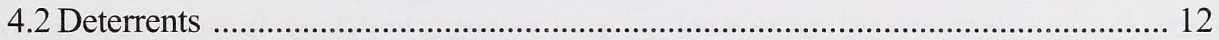

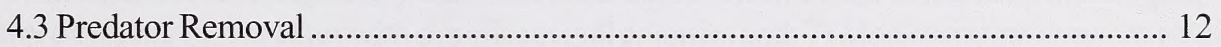

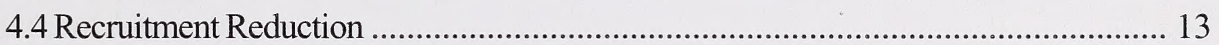

5.0 CONCLUSIONS AND RECOMMENDATIONS ................................................ 13

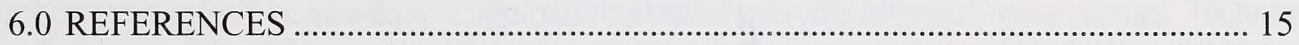

APPENDIX. Predator Control Methods ........................................................................ 19

\section{LIST OF TABLES}

Table 1. Example keywords used in database searches 


\section{ACKNOWLEDGEMENTS}

The Alberta Conservation Association (ACA) and Alberta Sustainable Resource Development, Fish and Wildlife Division provided funding for this project. Thank you to Medea Curteanu (ACA) for her assistance with the literature search and to Nyree Sharp (ACA) for editing and formatting this report.

Disclaimer: Mention of trade names and manufacturers is for identification only and does not imply endorsement by the authors or agencies involved with the report. 


\section{EXECUTIVE SUMMARY}

The piping plover (Charadrius melodus) is listed as Endangered under Alberta's Wildlife Act, and in most other jurisdictions in North America (Alberta Piping Plover Recovery Team 2002). Poor productivity as a result of predation of eggs and chicks has been identified as the greatest source of reproductive failure for piping plovers in Alberta. The Alberta Piping Plover Recovery Plan 2002-2004 identified a need for increased predator management in order to boost reproductive success (Alberta Piping Plover Recovery Team 2002). This report was produced in order to research and compile information on the various tools, techniques and tactics used to control predators thought to be a threat to piping plover reproductive success. This information was compiled through searches of a variety of bibliographic databases and Internet resources.

A wide variety of predator control techniques with potential application to piping plover management was identified. The most useful techniques should have tangible benefits for plover productivity and pose no safety or disturbance concerns for humans. As a rule, they should also be inexpensive relative to the benefits of employing the technique, require little manpower to implement and should be non-lethal to the predator species. With these criteria in mind, predator deterrence activities to be considered are: 1) using predator exclosures on as many nests as possible; 2 ) continued removal of stick nests during the nonbreeding season around key plover breeding lakes; 3 ) using electrified predator fences to protect habitats with high nest densities that can be exclosed with relatively small amounts of fence; 4) experimentation with the use of chick shelters in areas with little or no natural cover; 5) filling of known canid dens near plover nesting beaches during the non-breeding season; 6) initiation of discussions with affected parties (recovery team, provincial and federal regulatory agencies, local landowners) on the desirability of and approaches to gull control on piping plover lakes with significant gull colonies and; 7) Monitoring progress on research into the use of scent deterrents.

It is likely that a combination of these techniques, tailored to individual lakes, would be the most effective. The best strategy will be an adaptive approach that takes into consideration many factors. Techniques that are implemented should be monitored to determine their effectiveness and periodically modified through consultation with the Alberta Piping Plover Recovery Team. 


\subsection{INTRODUCTION}

The piping plover (Charadrius melodus) is listed as Endangered under Alberta's Wildlife Act, and in most other jurisdictions in North America (Alberta Piping Plover Recovery Team 2002). A province-wide survey in 2001 found 150 individuals in the southeastern part of the province, which is a $50 \%$ decrease from a similar survey conducted five years earlier (Prescott 2001).

A number of factors that limit the size of piping plover populations have been identified. These include depredation on nests, chicks and adults, vegetation encroachment, drought, livestock grazing, industrial development, water management activities, human disturbance, and habitat alterations on the wintering grounds (Prescott 1997, Alberta Piping Plover Recovery Team 2002, Goossen et al. 2002). In Alberta, the most significant of these is nest losses to avian and mammalian predators. Specifically, over $50 \%$ of piping plover nests are depredated each year in Alberta (Richardson 1999). Additional predation on unfledged chicks and adults can be substantial (Haig 1992, Michaud and Prescott 1999), and can contribute to very low recruitment for this species. Although predation is a natural event, many of the known predators of piping plovers have experienced population increases in recent decades, because these species thrive in human-altered landscapes (Haig 1985). Any management that minimizes the impact of predators is therefore beneficial to recovery efforts for the piping plover in Alberta and elsewhere. The protection of nests using wire predator exclosures has been a major management activity in Alberta since 1995 (Engley and Schmelzeisen 2003). This simple procedure virtually eliminates nest predation, but affords no protection for hatched chicks or adult birds.

The recently completed Alberta Piping Plover Recovery Plan 2002-2004 recognizes the need to reduce the impact of predation on breeding piping plovers (Alberta Piping Plover Recovery Team 2002). As a result, a literature search was undertaken to review and synthesize techniques that have been used to minimize the effects of predator populations that occur in Alberta. This manuscript summarizes the results of that search and recommends actions that may have substantial benefits for enhancing populations of piping plovers.

\subsection{METHODS}

\subsection{Literature Search}

Information communicated in this document was obtained through extensive searches of the University of Alberta Library system, through internet search engines, and through documents held at the Alberta Conservation Association office in Edmonton, Alberta and at the Sustainable Resource Development Office in Red Deer, Alberta. Searches were not intended to yield an exhaustive compilation of techniques and references, but rather to provide an overview of available techniques that may be applicable to piping plover management in Alberta and elsewhere.

Keyword searches of online databases began with general descriptive words such as "piping plovers" and "pest control methods", and then grew more specific as information was obtained. Table 1 lists some keywords that were used in the research for this project. 
Table 1. Sample keywords used in database searches.

\begin{tabular}{|l|l|l|}
\hline Piping plovers & Automatic scare devices & Crow control \\
Pest control methods & Predator removal & Frightening devices \\
Common terns & Bird deterrence & Gull poisoning \\
Piping plover predation & Nest predation & Monofilament lines \\
Shorebird predation & Bird control & Bird control devices \\
Duck predation & Mammal control & Egg oiling \\
Bird repellents & Coyote control & \\
Repellents & Gull control & \\
\hline
\end{tabular}

\subsection{Identification of Potential Predators}

Research conducted within and outside of Alberta on piping plovers and other wetland-dependent species was analyzed to produce the following list of potential predators of piping plovers or their eggs. In Alberta, observations of piping plover predation have been recorded for some, but not all of the species listed below. However, it is important to consider all potential predators, as predation events are rarely viewed and it is difficult to determine the impact that a particular species may have on piping plovers.

\section{Canines}

Canines acknowledged as potential piping plover predators include coyotes (Canis latrans), red foxes (Vulpes vulpes) and domestic dogs (Canis familiaris). Coyotes are common around Alberta lakes and were identified by Heckbert (1994) as potential predators of unprotected nests. Red foxes have been found depredating chicks and eggs in Maryland (Loegering and Fraser 1995) and Massachusetts (MacIvor et al. 1990). Heckbert (1994) identified domestic dogs as potential predators in Alberta.

\section{Corvids}

American crows (Corvus brachyrhynchos) and black-billed magpies (Pica pica) were observed conducting nest searches for piping plover eggs at Reflex and Killarney lakes within Alberta (Heckbert 1994). One case of a common raven (Corvus corax) preying upon a piping plover nest was also recorded in Alberta (L. Engley, pers. obs.). American crows were identified as the top predator of piping plover eggs in Massachusetts (MacIvor et al. 1990) and among the top predators in South Dakota (Kruse et al. 2002).

\section{Felines}

Heckbert (1994) identified domestic cats (Felis catus) as potential predators in Alberta.

\section{Ground Squirrels}

Franklin's ground squirrel (Spermophilus franklinii) and thirteen-lined ground squirrel ( $S$. tridecemlineatus) were identified as nest predators in North Dakota (Mayer and Ryan 1999). Richardson's ground squirrel (S. richardsonii) and Franklin's ground squirrel were identified as potential predators of piping plovers in Alberta, though no cases of predation have been observed (Heckbert 1994). 


\section{Gulls}

In Virginia, herring gulls (Larus argentatus) were observed taking a piping plover chick (Penn and Ailes 2003) and in Massachusetts, gull tracks (species unknown) were seen near two depredated piping plover nests (Koch 1999). In Alberta, "black-headed" and "white-headed" gulls have been identified as the top potential piping plover predators at Reflex Lake (Heckbert 1994). These are believed to be Franklin's gulls (Larus pipixcan), Bonaparte's gulls (Larus philadelphia), ring-billed gulls (Larus delawarensis), California gulls (Larus californicus) and herring gulls. The same study regarded "black-headed" gulls as the dominant predators of piping plovers at Killarney Lake and suggested that herring gulls and ring-billed gulls are also very likely to be predators. Low to nonexistent chick fledgling numbers on Little Fish and Akasu lakes in Alberta may be due to gull colonies existing near piping plover nesting beaches (D. Prescott, pers. obs.).

\section{Mustelids}

Striped skunks (Mephitis mephitis) were identified as the second most common nest predators on piping plover nests in Massachusetts (MacIvor et al. 1990). Mink (Mustela vison) were among the leading predators of nests in South Dakota (Kruse et al. 2002), where American badgers (Taxidea taxus) and long-tailed weasels (Mustela frenata) were also found preying upon nests (Mayer and Ryan 1999).

\section{Raccoons}

Raccoons (Procyon lotor) are an uncommon resident in Alberta, but populations are increasing and the species may pose a threat to plover nests where raccoon populations do occur. Raccoons were identified as significant nest predators in South Dakota (Kruse et al. 2002).

\section{Raptors}

In South Dakota, American kestrels (Falco sparverius) and great horned owls (Bubo virginianus) were identified as the top raptor predators of piping plover chicks in 1991 and 1992 and were responsible for $93 \%$ of documented chick mortalities (Kruse et al. 2002). In 1999, merlins (Falco columbarius) attacked and killed 23 piping plover adults in Alberta (Michaud and Prescott 1999). Northern harriers (Circus cyaneus) are known to depredate least tern (Sterna antillarum) chicks (Mostello and Melvin 2001) and have been seen near piping plover nesting beaches. However, no records have been found linking them to depredation of piping plovers.

\section{Snakes}

Snakes are known egg predators and were identified by Heckbert (1994) as being potential predators of piping plovers and their eggs in Alberta.

\subsection{RESULTS}

\section{$\underline{3.1 \text { Search Results }}$}

In this literature search, 24 articles were found through internet searches pertaining to piping plovers or predator control, 9 informational web site documents were found concerning predator control, 10 advertising web sites were found which offered predator control devices and 56 articles were found through library searches, as PDF documents or at the offices in Edmonton or Red Deer. 
Below is a summary of techniques found that have some relevance to piping plover management. The Alberta Piping Plover Recovery Plan 2002-2004 states that predators are to be managed in a passive way which precludes the use of methods that may injure or kill the predator (Alberta Piping Plover Recovery Team 2002). Control techniques were considered with this in mind, although lethal methods were reviewed for comparison purposes. Control techniques were grouped into four broad categories: barriers, deterrents, predator removal and recruitment reduction. Specific information on each method of control is listed below and summarized in the Appendix.

\subsubsection{Barriers}

Barrier devices are designed to keep the problem species out of a chosen area. A barrier must not restrict piping plover adult or chick mobility if it is to be used on beaches occupied by these birds. Barriers applicable to piping plover management include chick shelters, fences and predator exclosures.

\section{Chick shelters}

Chick shelters are designed to protect chicks primarily from aerial predators by providing a structure under which the chick can run and hide. A simple method is to nail two pieces of plywood (approx. $12.5 \times 25.0 \mathrm{~cm}$ ) together in an "A"-frame configuration. Use of such shelters on a common tern colony on Lake Erie was highly successful - predation of common tern chicks by gulls was reduced to zero (Burness and Morris 1992). Similar shelters used along the Missouri River by Kruse et al. (2002) had less favourable results when tested on tern and piping plover chicks. It was suggested that the reason for this could have been the extensive vegetated areas and driftwood along the river that already provided plenty of shelter for piping plover chicks.

\section{Fences}

Fences can provide protection from most mammalian predators if constructed properly. Electric woven-wire fences increased mean nest survival of plovers by $71 \%$ in North Dakota (Mayer and Ryan 1999). These fences were constructed by driving T-posts around the beach area and $25 \mathrm{~m}$ into the water at $5-\mathrm{m}$ intervals. A $1.3-\mathrm{m}$ high, $2.5-\mathrm{cm}$ wire mesh was strung along the T-posts with the bottom portion draped slightly outward on the substrate and staked to the ground. Three strands of electrically charged 17 -gauge wire were then fastened with plastic clips to the mesh along the outside of the fence line at 10,65 , and $130 \mathrm{~cm}$ above the ground.

To prevent coyotes from leaping over fences, the Missouri Department of Conservation (1997) recommends using net or woven-wire fences standing seven feet or higher unless high tensile wire is placed above the woven wire. High tensile electric fences with at least seven alternating strands of ground and current-carrying wire can also be effective. The bottom wire should be hot.

This form of barrier provides no protection from avian predators. Fences may also provide a perching area for avian predators unless a hot wire is run along the top of the fence. Price and material bulk and weight may be prohibitive unless a high density of nesting or feeding birds frequents an area. To reduce the above shortcomings, fences may be designed for easy setup and removal and could be strategically located such as at the base of a peninsula to minimize length. Fences should frequently be checked for weak spots such as grounded wires to prevent predators from passing through. 


\section{Predator exclosures}

Predator exclosures are removable cages erected directly around the nest to protect from both mammalian and avian predators. These cages have been successfully used for piping plover recovery projects in the USA and in Canada. Use of predator exclosures has increased apparent nest success in South Dakota from 34.4\% to 61.6\% (Kruse et al. 2002) and in Alberta, nest success rates have been as high as $93 \%$ on enclosed nests compared to $43 \%$ on unprotected nests (Engley and Schmelzeisen 2002). However, no substantial difference in nest success was attributed in Colorado when exclosures were applied to piping plover, snowy plover (Charadrius alexandrinus) and killdeer (Charadrius vociferous) nests. It was suggested that part of the reason could have been higher numbers of small mammalian and reptilian predators in Colorado than in other tested areas (Mabee and Estelle 2000).

Material, design and set-up of predator exclosures vary. Recommended material for exclosure walls is galvanized wire fence with $5.0 \mathrm{~cm} \times 5.0 \mathrm{~cm}$ holes or $10.0 \times 5.0 \mathrm{~cm}$ holes, so that incubating piping plovers can freely enter and leave the exclosure. Netting is preferred for covering the top, along with some method to prevent birds from perching on the exclosure (such as cutting the top horizontal wire off of the walls to leave a ring of spikes). Netting should be $2 \mathrm{~cm} \times 2 \mathrm{~cm}$ or less (Atlantic Coast Piping Plover Recovery Team 1996). Iron T-bars and/or rebar weaved through fence holes and pegs hooked to the wire mesh may be used to provide support for the exclosure and help secure it in the substrate.

Tested exclosure designs include triangular, circular and rectangular bases and have all yielded desirable results. Recommended size varies. While large exclosures with a base area of $7-8 \mathrm{~m}^{2}$ and standing 0.8-1.2m high have been used successfully (Melvin et al. 1992, Engley 2001), these structures do attract unwanted attention from curious predators, cattle, perching birds, domestic dogs and people (Atlantic Coast Piping Plover Recovery Team 1996, Engley 2001). The Atlantic Coast Piping Plover Recovery Team (1996) suggested not using exclosures smaller than a base area of 7.3 $\mathrm{m}^{2}$ and $91 \mathrm{~cm}$ in height, arguing that incubating adults may be startled off of the nest and hit the exclosure wall or that small designs allow predators to more easily locate what is inside the exclosure. However, very small exclosures with a base area of $0.3 \mathrm{~m}^{2}$ and standing $0.4 \mathrm{~m}$ high have been widely used and closely monitored in Alberta with no indication of either condition occurring. In three years of use, 94\% of exclosed nests have hatched (Engley 2001, Engley and Schmelzeisen 2002, Schmelzeisen and Engley 2003). In Alberta, small exclosures are thought to be less conspicuous than larger varieties, therefore decreasing the likelihood of unwanted visitation (Engley 2001).

Setup time should not exceed 20 minutes and should be practiced before actual application (Atlantic Coast Piping Plover Recovery Team 1996). Two or more researchers are needed to erect large exclosures and setup time can range from 10-30 minutes (Heckbert and Cantelon 1996). For the small exclosures, one researcher is needed and setup time can be as little as 30 seconds if exclosures are put together ahead of time and need only be secured (Engley 2001). When exclosures use bars for support, the bars should be pushed into the ground to a level below the top of the fence wall to prevent perching. After setup, nests should be monitored until an adult returns to the nest. If an adult does not return to the nest within 60 minutes of setup, the exclosure should be removed. Exclosure-treated nests should be monitored at least every other day and exclosures should be removed if there is evidence that they are inhibiting nest success (Atlantic Coast Piping Plover Recovery Team 1996). 


\subsubsection{Deterrents}

Deterrents, or repellents, are devices used to scare a pest from an area. Several types of deterrence techniques exist, including automatic noise repellents, behaviour-modifying chemicals, electromagnetic devices, effigies, human presence, light repellents, mobiles, pyrotechnics, scent repellents and suspended lines.

\section{Automatic noise repellents}

Automatic noise repellents are considered one of the most effective methods available for dispersing bird species (Transport Canada 2002). There is a wide array of automatic noise repellents. Common varieties include timed automatic cannons, electronic noisemakers, bird alarm and distress calls, and calls of predatory birds (see below). These devices are often used together with visual deterrents such as mobiles, effigies and/or lights. The usefulness of these devices for piping plover predator management is limited, as they are likely to disturb plovers as well as the problem species. The only possible exception to this is the bird distress and alarm calls. According to Transport Canada (2002), most birds respond only to calls of their own species.

Timed automatic propane- or acetylene gas-powered cannons emit a loud explosive blast, and time intervals between blasts may be adjusted. Some models rotate and/or automatically turn on and off (Curtis et al. 1996).

Electronic noisemakers produce a large variety of synthetic noises and tend to be easier to acquire than models that emit bird calls (Transport Canada 2002). Electronic noisemakers have, however, been cited by as being largely ineffective (Curtis et al. 1996). This is especially true for ultrasonic noisemakers, as there is evidence that birds can't hear ultrasonic wavelengths (Mason and Clark 1997).

Bird calls, such as vocalizations from predators of the target species or alarm or distress calls of the target species tend to have a slower rate of habituation, but can be more difficult to acquire. Bird calls are often species-specific and even region-specific; therefore, a recording of the intended species should be made from the same area in which it will be broadcast (Transport Canada 2002). Some birds may need to hear two or more different recorded calls before they will disperse. For example, herring gulls require the broadcast of an initial distress call followed by an alarm call in order to be dispersed (Transport Canada 2002). Predator calls should be from a primary predator of the species in the area.

One advantage to using automated noise repellents is that the devices can be set up in an area without constant supervision. These devices can be rather costly as prices can range between $\$ 200$ and $\$ 5500$ U.S. (Nixalite of America 2001). Care should be taken to choose locations for setup where the chance of theft or vandalism is minimal. Efficiency of noise deterrents increases greatly if combined with visual deterrents, such as mobiles, light repellents and effigies, provided that the visual deterrents are frequently relocated (Transport Canada 2002).

\section{Behaviour-Modifying Chemicals}

Behaviour-modifying chemicals cause visual and acoustic deterrence by inducing erratic behaviour in the animals that digest them (Transport Canada 2002). Chemicals, such as Avitrol (4aminopyridine) have been used in non-lethal dosages that cause visible signs of distress in the affected birds and frighten other birds nearby. The target area is normally pre-baited for a time 
before the chemical is applied (Transport Canada 2002). These chemicals can be lethal in high dosages.

\section{Effigies}

Effigies come in a variety of forms. Appearances often resemble humans (i.e. scarecrows), predators of the pest species, carcasses of pest species or giant eyes. As with most forms of deterrent, pest species will eventually habituate to effigies. Habituation can be slowed down if effigies are periodically moved (i.e. every two to three days) and if they are used in conjunction with noise deterrents (Transport Canada 2002). To reduce static appearance, some effigies are balloons or kites or come with moving heads or ribbon tape. Effigies resembling gull carcasses have been used to keep gulls from an area for periods of eight days to eight months (Transport Canada 2002), but require models that closely resemble actual dead birds of the chosen species.

\section{Electromagnetic Devices}

Laboratory research has shown that magnetic fields can affect animal behaviour. This has prompted some enterprises to produce electromagnetic generators that emit an oscillating electromagnetic impulse designed to repel a variety of species including coyotes, foxes, ground squirrels, pocket gophers, mice, voles and rats. These devices are usually buried in the ground and require a 110-volt power source. These electromagnetic generators can cost several hundred dollars and quantitative efforts have yet to prove that these devices repel wildlife at all (Transport Canada 2002).

\section{Human Presence}

Human presence in an area can be a very effective form of predator deterrence (U.S. Fish and Wildlife Service 2000). Besides regular patrols, managers may set up field camps or enlist volunteers to periodically walk a target area. Effectiveness of human presence can be increased by use of pyrotechnics (Curtis et al. 1996).

\section{Light Repellents}

Lights used to repel pest birds come in a variety of forms such as floodlights, flashing lights, revolving beacons or low-power laser beams. Light repellents work best under low light conditions. The U.S. Department of Agriculture (2001) found no habituation to lasers when tested on doublecrested cormorants and Canada geese. Conversely, sodium iodide lights were tested in Oklahoma (James et al. 1999) with no effect on birds roosting and nesting on electrical substations. Sodium iodide lights were used because they do not emit the blue band of light that attracts insects and, consequently, their predators (birds or bats). Lasers employing red light (wavelengths between 660-665 $\mathrm{nm}$ ) are ineffective against mammalian predators, but blue-green lasers (wavelengths of $500 \mathrm{~nm}$ ) may be very effective (Mason and Bodenchuk 2002). Some automated noise repellents may be fitted with a light repellent.

\section{Mobiles}

This category includes various devices that are inexpensive and use movement to frighten an animal. Flags, pinwheels and reflective streamers fit into this category. Wildlife can quickly habituate to these devices and they tend to be only minimally effective in long-term projects unless incorporated into other management techniques (Transport Canada 2002).

\section{Pyrotechnics}

Pyrotechnics come in a variety of forms including shell crackers, powder shells, "bangers", "screamers", "whistle bombs", "screamer rockets", firecracker ropes, blanks and live ammunition. 
Their advantage over noise repellents is that they also provide a visual deterrent. Their main limitation is that they must be administered by people and can pose safety risks to users or others in the area.

Shell crackers and powder shells are considered an effective and useful form of deterrent for a variety of situations (Booth 1994). These munitions are fired from a 12-gauge shotgun and can be shot up to $100 \mathrm{~m}$ before exploding. Similar devices, commonly referred to as "bangers" (which produce a loud explosion) and "screamers" or "whistle bombs" (which produce a loud screeching or whistling noise), are fired from a $15-\mathrm{mm}$ or $17-\mathrm{mm}$ pistol and cover a slightly shorter distance. Screamer rockets are launched from a stationary platform. Sometimes live ammunition or blanks have been used to disperse birds (Curtis et al. 1996).

Firecracker rope is a relatively inexpensive method of scaring birds (Booth 1994). In this method, firecrackers known as fuse-rope salutes or agricultural explosive devices are inserted through a $5 / 16$ inch $(8 \mathrm{~mm})$ or $3 / 8$ inch $(9.5 \mathrm{~mm})$ cotton rope. By altering the spacing between firecrackers on the rope, explosion time intervals can be controlled.

Gun-loaded devices and rockets offer visual and noise deterrence and can be shot over areas that are hard to access (e.g., islands). Since these devices require human administration, they do not provide the same kind of hands-free deterrence offered by automatic noise repellents. Also, gun-loaded devices may be disturbing to nesting non-target shorebirds (particularly piping plovers) and to nearby human residents. Safety can be an issue as well, particularly if live ammunition is used.

\section{Scent Repellents}

Several web pages (e.g., Snow Pond Farm Supply 1999, Predatorpee 2003) promote scent repellents, such as wolf, coyote or bobcat urine in liquid and powdered form. These manufacturers claim that these substances may be spread over an area to scare away mammalian pests. However, Mason et al. (2001) state that there is no published data as yet to support this claim. Renardine $72-2^{\mathrm{TM}}$,a chemical agent, is another form of scent deterrent that tricks a target animal into believing that a rival animal is on the territory. The London Borough of Barking and Dagenham (2003) considers Renardine to be the most effective liquid repellent of foxes. The Renardine website (2003) advertises that animals known to respond to this chemical include foxes, badgers, dogs, cats, rabbits and moles. It is possible that coyotes could respond to this agent as well, but early testing has shown no measurable effect of Renardine on this predator (Zemilcka and Mason 2000).

The use of chemical deterrents is an active area of research (Mason et al 2001). Results of these investigations should be monitored for future applicability to piping plover management.

\section{Suspended Lines}

Suspended lines have been used on numerous occasions to keep gulls away from ponds or buildings (Blokpoel and Tessier 1984). They are highly effective against gulls even though they do not actually physically bar the gulls from an area. Other species of birds are able to fly under the wires and are often not as affected by the lines (Solman 1994). Lines are usually suspended $1 \mathrm{~m}$ or more above the ground (Transport Canada 2002).

Recommendations for spacing and line weight vary. Wires have been spaced up to 30 feet $(9 \mathrm{~m})$ apart at garbage sites and have successfully kept gulls away. As for line weight, Transport Canada 
(2002) states that the line must be $0.5 \mathrm{~mm}$ or less to be effective. Steel cables (28-gauge [0.36 mm]) and nylon monofilament lines (50-pound [23-kg] test) have both given positive results (Solman 1994).

Daddi Long Legs TM (Biocontrol Network 2002) are bird repellent devices consisting of several stainless steel rods that radiate from a plastic base. These devices come in two sizes- the suspended wires splay in a four or eight foot circle, making it unlikely that an animal would become tangled in these devices. Daddi Long Legs ${ }^{\mathrm{TM}}$ cost between $\$ 44.00$ and $\$ 56.75$ U.S. each.

\subsubsection{Predator Removal}

Predator removal tends to be a more selective method of depredation control than repellents or barriers. This technique may be lethal or non-lethal. Though ethically debatable, lethal removal was considered the primary reason that gulls did not frequent a control area set up by managers in Massachusetts, which resulted in increased piping plover nesting (Koch 1999). Predator removal may therefore need to be considered if passive forms of deterrence are not effective. Some methods of removing predators include shooting, poisoning and trapping.

\section{Poison}

Poison is a common method of control. Avitrol ${ }^{\mathrm{TM}}$ (4-aminopyridine) in lethal dosages, polybutenes and methyl anthraniltate are common poisons used on gulls. There is a danger when using these chemicals that the poison will not act in an expedient manor. This occurred in a program in Massachusetts, forcing researchers to euthanize 180 gulls, and resulted in a serious public outcry (Melley 1997). There is also a risk to non-target species and people; therefore, caution should be used if this method is considered.

\section{Shooting}

Shooting of problem species is a highly selective form of control. Persistent birds can be quickly removed to prevent other birds of the same species from losing their fear of an area. In Massachusetts, dyes were put on eggs within management areas in order to mark nesting gulls. These gulls were then shot or trapped when seen. Used with other forms of predator control, this system reduced gull nesting attempts from 1710 to 13 within three years (Koch 1999). This method permanently removes stubborn re-nesters and scares away many potential nesters. However, it does require special permits and may be unsafe or ethically unfavourable in some areas.

\section{Traps}

Traps come in various forms and include lethal and live traps. Traps may be set at nest/den sites, feeding areas or other areas frequented by the problem species. Nest traps were successful when used on gulls in the Massachusetts piping plover recovery project. However, the same study found that box traps for catching coyotes were unsuccessful (Koch 1999). The Missouri Department of Conservation (1997) also stated that coyotes are often too wary to be caught in cage traps and that live trapping can cause a considerable amount of stress on an animal and may result in the animal injuring itself. Safety issues may also arise with handlers and curious people, livestock, pets or wild animals. Managers relying on traps should use skilled trappers, adopt flexible work schedules for the trappers and provide them with the greatest possible choice of removal methods (Sargeant et al. 1995). 


\subsubsection{Recruitment Reduction}

Recruitment reduction control methods attempt to reduce the prevalence of predation by removing natal sites or preventing successful rearing of young predators. Some methods include active nest destruction, egg sterilization, inactive nest removal and den destruction.

\section{Active Nest Destruction}

Active nest destruction is a simple technique where the eggs are crushed or removed or the nest itself is removed. This method was used as part of the Massachusetts piping plover recovery program (Koch 1999). Used with other forms of predator control, this system reduced gull productivity from 1710 nests to 13 nests within three years (Koch 1999). Destruction of gull nests was conducted in Minnesota and prevented ring-billed gulls from establishing a major breeding colony near piping plover beaches (Maxson and Haws 1999).

Studies by Christens and Blokpoel (1991) and by Solman (1994) both stated that removal and disposal of eggs is more time-consuming and labour-intensive than spraying oil (see egg sterilization below). They also found that birds will usually try to reinitiate nests after they are destroyed. However, this method of recruitment reduction may be less harmful to the surrounding environment than some egg sterilization techniques.

\section{Egg Sterilization}

Egg sterilization is similar to egg destruction but prevents pest birds from re-nesting by tricking the bird into incubating the nest for the full term. Overall, sterilization is quite successful at reducing recruitment. Morris and Siderius (1990) found that oiling reduced hatchability to zero irrespective of embryo development in ring-billed gulls. In a study by Christens and Blokpoel (1991), oiling reduced hatchability in ring-billed gulls by $99.6 \%$ and in herring gulls by $100 \%$. Oiling $7-15$ days before expected hatching dates reduced herring and ring-billed gull recruitment by $89 \%$ in a study done by Blackwell et al. (2000).

Petroleum and white mineral oils are two forms of oil that have been used for egg sterilization. Though more expensive, Christens and Blokpoel (1991) suggest the use of the latter because white mineral oil does not have adverse effects on the surrounding environment. Two applications are suggested for $100 \%$ nest failure. The first application is to be given late in the incubation period of the earliest nests and the second is to be given at a later date to get the nests that may have been missed by the first application. Other methods for killing the embryo include formalin injection, pricking the eggs with a needle or shaking the eggs (Solman 1994).

Egg sterilization is overall a more time-efficient and effective method of recruitment reduction than egg destruction. However, this method is more expensive, as oils must be purchased, and some oils may be harmful to the surrounding environment.

\section{Inactive Nest Removal}

Inactive nest removal may be conducted on corvid or hawk nests. Removal of inactive nests does not target corvids because they rebuild their nests each year, but targets predatory birds such as owls and merlins that do not build there own nests, but take over nests built previously by other species. Nests found in the uplands immediately surrounding piping plover nesting beaches are the primary concern. Removal of inactive stick nests has been carried out in Alberta for the last three years on crow and magpie nests in the uplands of Reflex and Killarney lakes. Nest removal should be carried 
out in the fall or winter, after birds have finished nesting for the year. There is very little cost associated with this method of predator control, but it is difficult to measure the success of this initiative in reducing the presence of predatory birds.

\section{Den Destruction}

Removing predator dens is a useful method to reduce hunting pressure in an area and should be done before predators choose a suitable den or before the young leave the den (Missouri Department of Conservation 1997). Transport Canada (2002) also regarded den destruction as a useful method of controlling coyotes in an area. Filling in or collapsing the dens of coyotes, foxes and badgers in the uplands surrounding beaches with high piping plover concentrations may persuade these predators to use dens further from the beach. Renardine ${ }^{\mathrm{TM}}$ can be applied to unoccupied fox dens, by soaking rags with the chemical and placing them deep within the den, along with soaking sand with Renardine and sprinkling the sand along the entrance (London Borough of Barking and Dagenham 2003). Application to dens of other carnivores may yield similar results.

\subsection{DISCUSSION}

The methods used to control predation on piping plovers in Alberta will depend upon a number of factors, including: possible disturbance the method would have on breeding piping plovers; management objectives and philosophies outlined in the Alberta Piping Plover Recovery Plan 20022004 (Alberta Piping Plover Recovery Team 2002); consideration of public opinion regarding the technique; resources in time, labour and money needed to implement and maintain the control method; the legality of the chosen technique; and the specific conditions of the area managed. Application of the above listed control methods will be considered with these issues in mind.

\section{$\underline{4.1 \text { Barriers }}$}

Alberta already uses predator exclosures for predator management on piping plover beaches. As they nearly double nest success, their continued use is advised. Unfortunately, predator exclosures do not protect piping plover chicks, which are precocial. Continued application of small exclosures is also advised, as large designs are more conspicuous on the beach and can attract predators, livestock or curious observers.

Chick shelters are a promising technique to try in Alberta as many of the lakes that support piping plover populations have little or no shelter in the vicinity of the nesting habitat. Shelters offer an inexpensive and easily implemented method of providing protection for young chicks from avian and mammalian predation. However, care should be taken not to make the shelters too high or visible, as avian predators may use them as perches and curious onlookers may be drawn to them.

Fences provide protection from mammalian predation and can be implemented in areas of high piping plover activity if cost-effective. A combination of electric and woven-wire fence as erected in North Dakota (Mayer and Ryan 1999) is likely to be the most effective form of fence. Spikes or electric wire must be run along the top of the fence, and fences should be as low as possible in order to reduce their utility as potential perches for raptors. 


\subsection{Deterrents}

Most bird repellents are auditory and/or visual in nature; therefore, they may have a limited use in plover management as they have the potential to repel plovers from an area along with the pest. In light of this, care should be taken to use these devices only where disturbance to plovers is minimal. These devices may be useful on gull colonies reasonably distanced from beach areas occupied by piping plovers. Perhaps they could also be used in upland areas around nesting beaches to frighten away mammalian predators.

Bird distress calls or predator calls combined with visual deterrents, such as mobiles, light deterrents and effigies seems a viable option on gull colonies. Playing alarm calls of the specific pest species may be less disturbing to piping plovers and more effective on the pest species than other noise generators, as there is evidence that birds often only respond to their own alarm calls (Transport Canada 2002). Alarm calls should be tested on a small scale and piping plover behaviour should be monitored closely before large-scale or long-term use of these calls is implemented.

Various types of visual deterrents could be tried; however, care should again be taken to ensure that these methods do not negatively affect piping plovers. Patrol or camps on gull colonies will also surely agitate the pest species and it may be possible to recruit volunteers on some lakes for such activities. Behaviour-modifying chemicals risk killing target and non-target animals and can be ethically questionable. Such chemicals are unlikely to be consistent with the guiding principles outlined in the Alberta Piping Plover Recovery Plan 2002-2004 (Alberta Piping Plover Recovery Team 2002) and as a result these management strategies and are not recommended for use in Alberta.

Suspended lines appear to be a viable option on lakes with active gull colonies that threaten piping plover productivity. However, the lines should be monitored regularly as there is a risk that lines may break and animals may get tangled. Some barrier should be erected to prevent large mammals (i.e. canines or ungulates) from tearing down the lines. Thicker cables should be used, as there is a risk with monofilament lines of birds getting tangled in the lines, particularly piping plovers or other sensitive species. Purchasing several Daddi Long Legs ${ }^{\mathrm{TM}}$ devices could solve this problem; however, the cost may be prohibitive.

Noise and visual deterrents may be useful in upland areas near piping plover beaches, but caution and frequent monitoring must be exercised if these methods are used as they may agitate piping plovers. Scent deterrents may be a viable option for upland habitats and are worth investigating.

\subsection{Predator Removal}

Lethal methods of predator removal such as shooting, poisoning and lethal traps are effective in removing specific problem animals but pose safety, legal and ethical concerns and are not consistent with the guiding principles outlined in the Alberta Piping Plover Recovery Plan 2002-2004 (Alberta Piping Plover Recovery Team 2002). However, they are effective in spot removing pests and can significantly increase the effectiveness of deterrence controls.

Predator removal through live trapping can be used if the traps are monitored frequently. Live traps can be used for gulls establishing nests on or near piping plover areas, or for predators that frequent 
a piping plover beach. Trapped animals should be marked if they are relocated, to determine whether they return.

\subsection{Recruitment Reduction}

Removal of inactive stick nests in the uplands surrounding piping plover nesting lakes during fall or winter months is a form of recruitment reduction that has been used for the past three years in Alberta. This has resulted in a decrease in the total number of stick nests around the lake in subsequent years (L. Engley, pers. obs.). Though it is difficult to determine the actual effect this has on piping plovers, it is an inexpensive method of control that requires little overall effort.

Removing mammalian dens in the early spring or late fall should also be considered, as this is also a simple, cost-effective approach to predator control. However, removal of inactive dens should be applied first, as destruction of active dens would be contrary to the guiding principles outlined in the Alberta Piping Plover Recovery Plan 2002-2004 (Alberta Piping Plover Recovery Team 2002).

Active nest destruction or egg sterilization could be used on gull colonies, gulls nesting on piping plover nesting beaches or in corvid nests. Ethical and legal issues should be clarified here as well before this method is used. If eggs are sterilized, white mineral oil is suggested, as it has less environmental impact than petroleum oil (Christens and Blokpoel 1991).

\subsection{CONCLUSIONS AND RECOMMENDATIONS}

Predator management is a controversial topic, but should be given strong consideration in the management of endangered species such as the piping plover (Hecht and Nickerson 1999). A wide variety of predator control techniques with potential application to piping plover management are available. Most of the techniques described are likely to have some benefit for plover management in Alberta. However, the most useful techniques are those that have tangible benefits for plover productivity and pose no safety or disturbance issues to humans. As a rule, they should be relatively inexpensive, require little manpower to implement and should be non-lethal to the predator species. Given these criteria, we recommend the following:

(1) Continued use of predator exclosures on nests throughout the province.

(2) Continued removal of stick nests during the non-breeding season around key plover breeding lakes.

(3) Use of electrified predator fences to protect habitats with high nest densities if the area can be exclosed with relatively small amounts of fence (e.g., peninsulas).

(4) Experimenting with the use of chick shelters in areas of low vegetation cover.

(5) Filling of known canid dens near plover nesting beaches during the non-breeding season.

(6) Initiating discussions with affected parties (recovery team, provincial and federal regulatory agencies, local landowners) on the desirability and approaches to gull control on piping plover lakes with significant gull colonies. If control is advocated, egg oiling is likely the most effective technique, but a variety of other deterrence techniques to control gulls are available.

(7) Monitoring progress on research into the use of scent deterrents. If proven effective, these chemicals could provide a useful tool for reducing mammalian predation on eggs and chicks. 
In practice, a combination of approaches to predator management is probably needed, depending on circumstances on individual lakes or nesting beaches (Mason et al. 2001). The best strategy will be an adaptive approach that considers many factors, that implements solutions and monitors their effectiveness, and that periodically modifies management based on accumulated knowledge (Hecht and Nickerson 1999). This philosophy is consistent with that of the Alberta Piping Plover Recovery Team (2002). 


\subsection{REFERENCES}

Alberta Piping Plover Recovery Team. 2002. Alberta piping plover recovery plan, 2002-2004. Alberta Sustainable Resource Development, Fish and Wildlife Division, Alberta Species at Risk Recovery Plan No. 2. Edmonton, AB. 21 pp.

Atlantic Coast Piping Plover Recovery Team. 1996. Guidelines for the use of predator exclosures to protect piping plover nests (Revised, February 1996). U.S. Fish and Wildlife Service. 6 pp.

Biocontrol Network. 2002. URL: http://www.biconet.com/birds/DaddiLL.html [Last Updated: May 2002]

Blackwell, B.F., T.W. Seamans, D.A. Helon and R.A. Dolbeer. 2000. Early loss of herring gull clutches after egg oiling. Wildlife Society Bulletin 29:70-75.

Blokpoel, H., and G.D. Tessier. 1984. Overhead wires and monofilament lines exclude ring-billed gulls from public places. Wildlife Society Bulletin 12:55-58

Booth, T.W. 1994. Bird dispersal techniques. URL: http://safety.kirtland.af.mil/AFSC/Bash/USDA/ BIRD/bird_e19.pdf. 5 pp.

Burness, G.P., and R.D. Morris. 1992. Shelters decrease gull predation on chicks at a common tern colony. Journal of Field Ornithology 63:186-189.

Christens, E., and H. Blokpoel. 1991. Operational spraying of white mineral oil to prevent hatching of gull eggs. Wildlife Society Bulletin 19:423-430

Curtis, K., W.C. Pitt, M.R. Conover. 1996. Overview of techniques for reducing bird predation at aquaculture facilities. Jack H. Berryman Institute. Department of Fisheries and Wildlife. College of Natural Resources. Utah State University. URL: www.extension.usu.edu/publica/ natrpubs/birdpre.pdf. $20 \mathrm{pp}$.

Engley, L. 2001. Use of predator exclosures to protect piping plover nests in Alberta and Saskatchewan. Unpubl. rep., Alberta Conservation Association, Edmonton, AB. 17 pp.

Engley, L. and R. Schmelzeisen. 2002. Alberta Piping Plover Predator Exclosure and Population Monitoring Program. Unpubl. rep., Alberta Conservation Association, Edmonton, AB. 22 pp.

Goossen, J.P., D.L. Amirault, S. Richard, R. Bjorge, J. Bazil, S. Brechtel, R. Chiasson, G.N. Corbett, F.R. Curley, M. Elderkin, S.P. Flemming, W. Harris, L. Heyens, D. Hjertaas, M. Huot, R. Jones, W. Koonz, P. Laporte, R.I.G. Morrison, C. Stewart, L. Swanson and E. Wiltse. 2002. National recovery plan for piping plover (Charadrius melodus). National Recovery Plan No. 22. Recovery of Nationally Endangered Wildlife. Ottawa, ON. 47 pp.

Haig, S.M. 1985. Updated status report on the piping plover Charadrius melodus in Canada. Committee on the Status of Endangered Wildlife in Canada, Ottawa, ON. 23 pp. 
Haig, S.M. 1992. Piping plover. Pages 1-18 in Poole A., P. Stettenheim and F. Gill (eds.). The birds of North America, No. 2. The Academy of Natural Sciences, Philadelphia, PA, and The American Ornithologists' Union Washington, DC.

Hecht, A. and P.R. Mickerson. 1999. The need for predator management in conservation of some vulnerable species. Endangered Species Update 16:114-118.

Heckbert, M.D. 1994. Piping plover (Charadrius melodus) ecology and conservation in Alberta (1994): Reflex Lake and Killarney Lake field report. Alberta Environmental Protection, Fish and Wildlife Service. Unpubl. rep. 94 pp.

Heckbert, M.D., and K.D. Cantelon. 1996. Piping plover (Charadrius melodus) ecology and conservation in Alberta (1995): east-central Alberta field report. Alberta Environmental Protection, Fish and Wildlife Service. Unpubl. rep. 163 pp.

James, J.B., E.C. Hellgren and R.E. Masters. 1999. Effects of deterrents on avian abundance and nesting density in electrical substations in Oklahoma. Journal of Wildlife Management 63:1009-1017.

Koch, S.L. 1999. Summary of field season activities in 1998 - North and South Monomoy Islands, Monomoy National Wildlife Refuge. U.S. Fish and Wildlife Service. 24 pp.

Kruse, C.D., K.F. Higgins and B.A. Vander Lee. 2002. Influence of predation on piping plover, Charadrius melodus, and least tern, Sterna antillarum, productivity along the Missouri River in South Dakota. Canadian Field-Naturalist 115:480-486.

Loegering, J.P., and J.D. Fraser. 1995. Factors affecting piping plover chick survival in different brood-rearing habitats. Journal of Wildlife Management 59:646-655.

London Borough of Barking and Dagenham. 2003. URL: http:/www.barking-dagenham.gov.uk/6living/public-health/pdf/hcs-pest-fsh-foxs.pdf. [Accessed: October 2003].

Mabee, T.J., and V.B. Estelle. 2000. Assessing the effectiveness of predator exclosures for plovers. Wilson Bulletin 112:14-20

MacIvor, L.H., S.M. Melvin and C.R. Griffin. 1990. Effects of research activity on piping plover nest predation. Journal of Wildlife Management 54:443-447.

Mason, J.R., and M.J. Bodenchuk. 2002. Depredation management outside the box: logical adaptations of successful practices with other species and situations. Pages 219-222 in Timm, R.M., and R.H. Schmidt (eds.). Proceedings of the $20^{\text {th }}$ Vertebrate Pest Conference, University of California. $395 \mathrm{pp}$.

Mason, J.R., and L. Clark. 1997. Avian repellents: options, modes of action, and economic considerations. Pages 371-391 in Mason, J. R. Repellents in wildlife management: proceedings of a symposium. Proceedings of the Second DWRC Special Symposium (August 8-10, 1995, Denver, CO). National Wildlife Research Center, Fort Collins, CO. URL: www.aphis.usda.gov/ws/nwrc/is/repellents/pdf/mason.pdf. [Last updated: 03/14/2003] 
Mason, J.R., J.A. Shivik and M.W. Fall. 2001. Predation management - chemical repellents and other aversive strategies in predation management. Endangered Species Update 18:175-181

Maxson, S.J., and K.V. Haws. 1999. Effects of predator removal and gull control at a breeding site for piping plovers and common terns on Lake of the Woods, Minnesota. URL: http:// www.greatplains.org. [Accessed: October 2003].

Mayer, P.M., and M.R. Ryan. 1999. Electric fences reduce mammalian predation on piping plover nests and chicks. Wildlife Society Bulletin 19:59-63. URL: http://www.greatplains.org/ npresource/1999/symbabs/electric.htm

Melley, B. 1997. Seagulls get reprieve; poisoning effort halted on Monomoy. SouthCoastToday.com, an edition of The Standard Times. URL: http://www.s-t.com/daily/02-97/02-02-97/ a03sr013.htm

Melvin, S.M., L.H. MacIvor and C.R. Griffin. 1992. Predator exclosures: a technique to reduce predation at piping plover nests. Wildlife Society Bulletin 20:143-148.

Michaud, I., and D. Prescott. 1999. Use of predator exclosures to protect piping plover nests in Alberta and Saskatchewan: 1999 field season report. Alberta Conservation Association, Edmonton, AB. 21 pp.

Minnesota Department of Natural Resources Nongame Program. 2001. Piping plover recovery and monitoring in Minnesota, 2000. U.S. Fish and Wildlife Service. 4 pp., 3 figs., 6 tables.

Missouri Department of Conservation. 1997. Damage prevention and control. URL: http:// www.conservation.state.mo.us/manag/coyote/control.html [Last updated: 1997].

Morris, R.D., and J. Siderius. 1990. A treatment for prevention of hatching in field-incubated ringbilled gull eggs. Journal of Wildlife Management 54(1):124-130.

Mostello, C.S., and S.M. Melvin. 2001. Summary of 2000 Massachusetts Piping Plover Census Data. U.S. Fish and Wildlife Service. URL: http://pipingplover.fws.gov/state/ma.html [Last updated: July 2001].

Nixalite of America Inc., Architectural Bird Control. 2001. Nixalite bird dispersal systems. URL: http://www.nixalite.com [Accessed: October 2003].

Penn, T., and I. Ailes. 2003. Chincoteague Natural History Association. URL: http:// www.assateague.org [Last Updated: April 2003]

Predatorpee. 2003. URL: http://www.predatorpee.com/main.html [Accessed: October 2003].

Prescott, D.R.C. 1997. Status of the piping plover (Charadrius melodus) in Alberta. Alberta Environmental Protection, Wildlife Management Division, Wildlife Status Report No. 1, Edmonton, Alberta. $19 \mathrm{pp}$. 
Prescott, D.R.C. 2001. The 2001 International Piping Plover Census in Alberta. Alberta Sustainable Resource Development, Fish and Wildlife Division, Alberta Species at Risk Report No. 27, Edmonton, AB. 15 pp.

Renardine. 2003. URL: http://www.roebuck-eyot.co.uk. [Accessed: October 2003].

Richardson, I.M. 1997. Guidelines for the use of predator exclosures to protect piping plover (Charadrius melodus) nests. Alberta Environmental Protection, Wildlife Management Division Report, Edmonton, AB. 21 pp.

Richardson, I.M. 1999. Predator exclosures: a management technique to increase piping plover reproductive success in the Canadian Prairies. M.Sc. Thesis, University of Alberta, Edmonton, AB. 65 pp.

Sargeant, A.B., M.A. Sovada and T.L. Shaffer. 1995. Seasonal predator removal relative to hatch rate of duck nests in waterfowl production areas. Wildlife Society Bulletin 23:507-513.

Schmelzeisen, R., and L. Engley. 2003. Alberta Piping Plover Predator Exclosure and Population Monitoring Program. Unpubl. rep., Alberta Conservation Association, Edmonton, AB. 15 pp.

Solman, V.E.F. 1994. Gulls - Damage Prevention and Control Methods. URL: http:// safety.kirtland.af.mil/AFSC/Bash/USDA/BIRD/bird_e49.pdf. 4 pp.

Snow Pond Farm Supply. 1999. URL: http://www.snow-pond.com/index.html. [Accessed: October 2003].

Transport Canada. 2002. Bird dispersion techniques and their effectiveness. URL: http:// www.tc.gc.ca/aviation/aerodrme/birdstke/manual. [Accessed: October 2003].

U.S. Department of Agriculture. 2001. Use of lasers in avian dispersal. URL: http:// www.aphis.usda.gov:80/oa/pubs/tnlasers.html. [Accessed: October 2003].

U.S. Fish and Wildlife Service. 2000. Monomoy National Wildlife Refuge - nesting season operating procedures, monitoring protocols, and competitor/predator management, 1998 2000. U.S. Fish and Wildlife Service, MA. 24 pp.

Zemlicka, D., and J.R. Mason. 2000. Response of captive coyotes to Renardine coyote repellent. Proceedings of the vertebrate pest conference 19:336-338. 


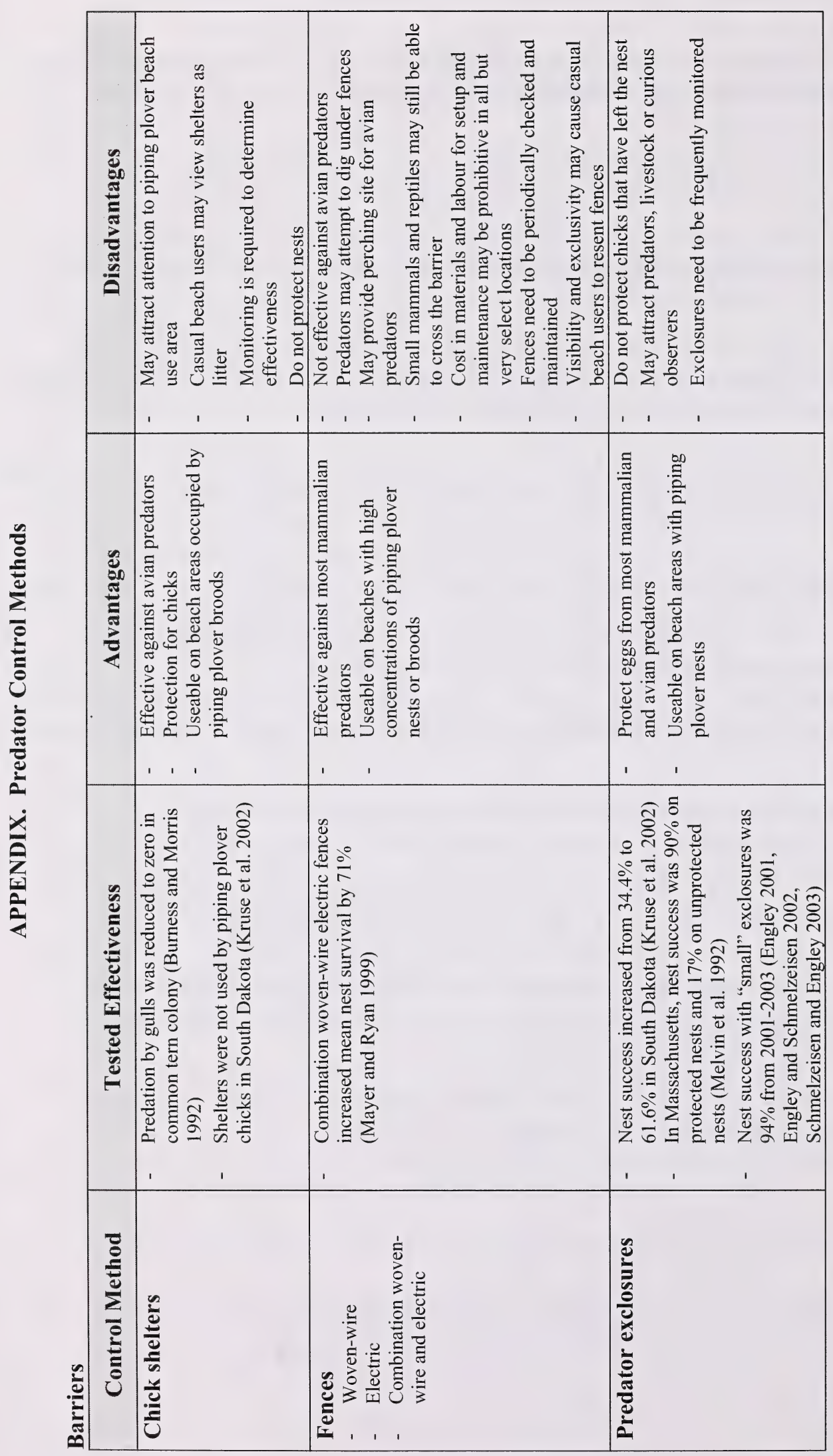




\begin{tabular}{|c|c|c|c|}
\hline & 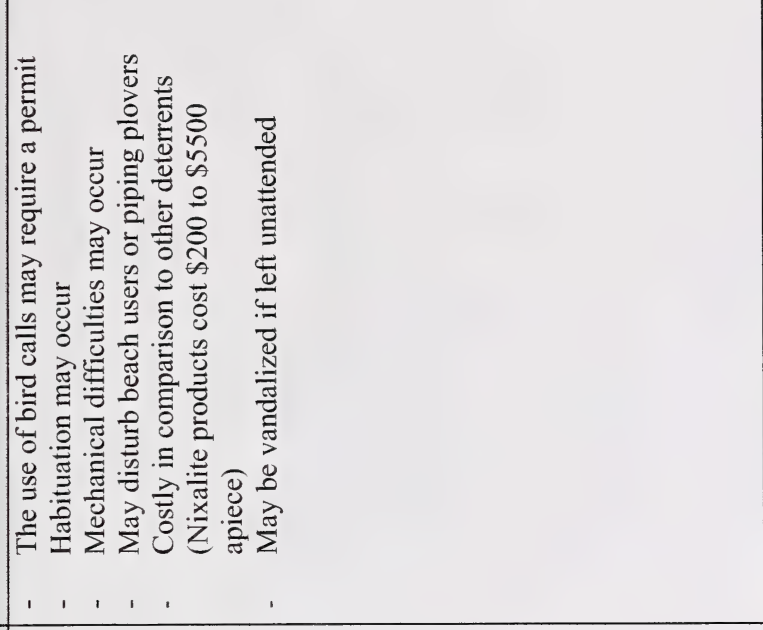 & 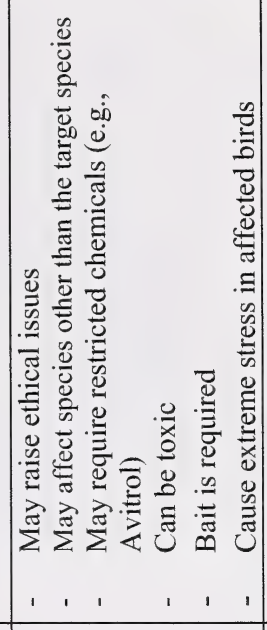 & 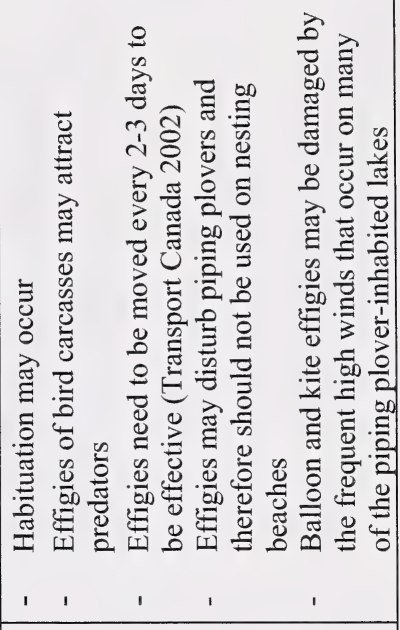 \\
\hline & 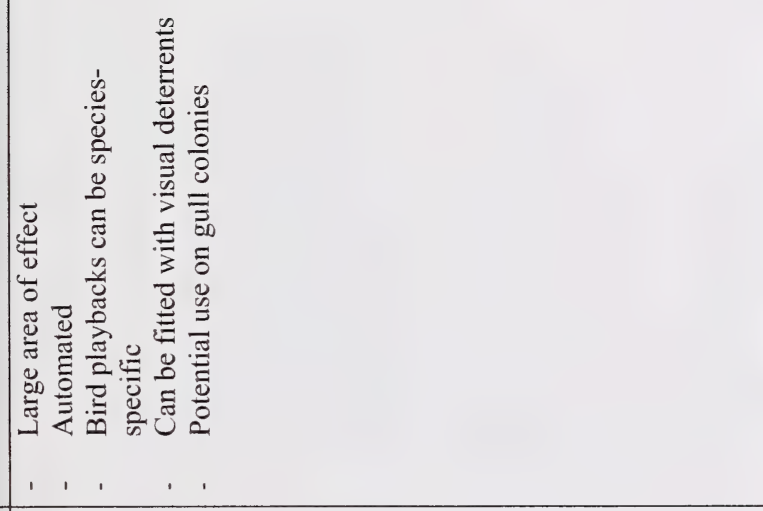 & 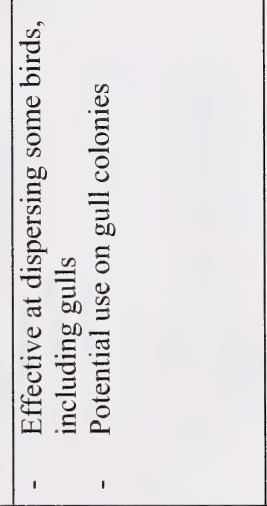 & 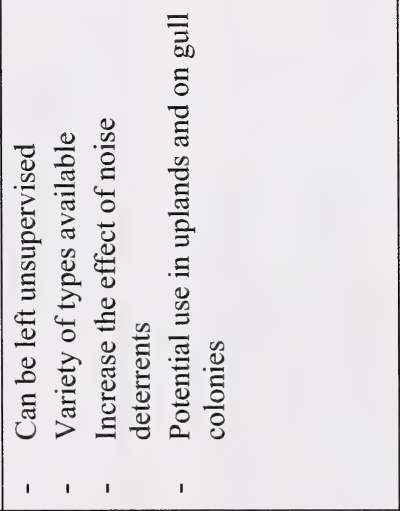 \\
\hline 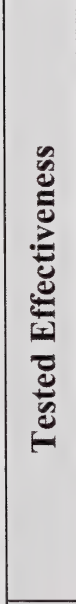 & 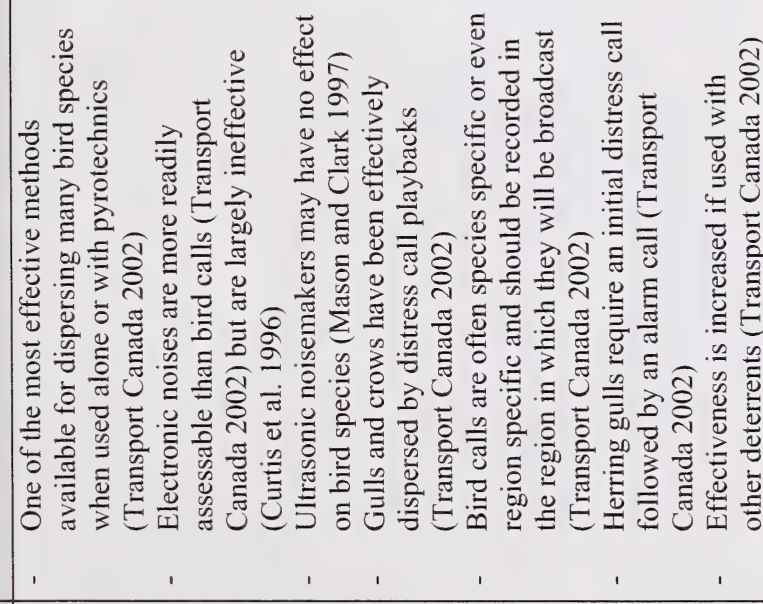 & 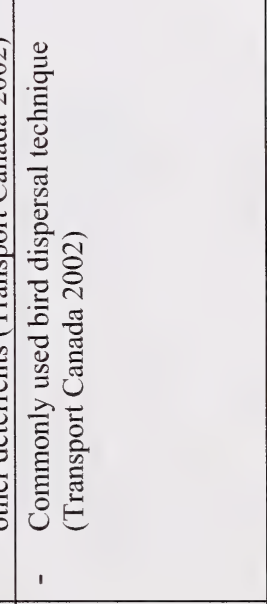 & 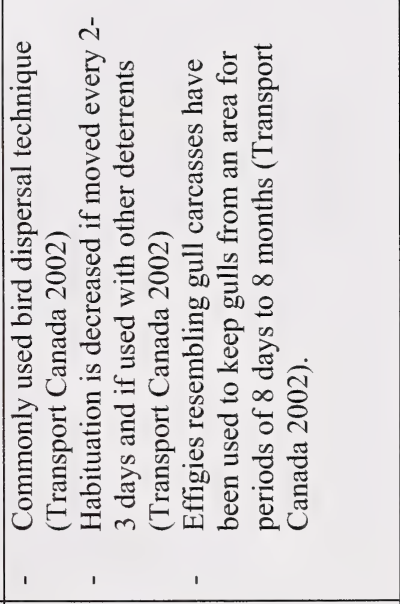 \\
\hline 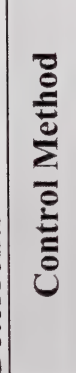 & 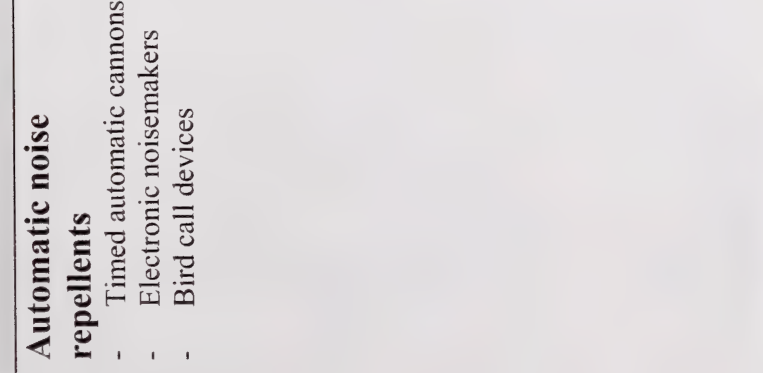 & 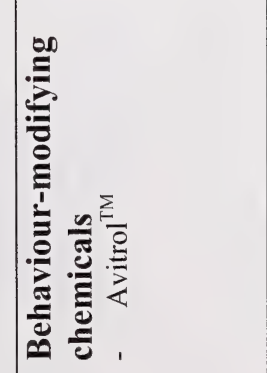 & 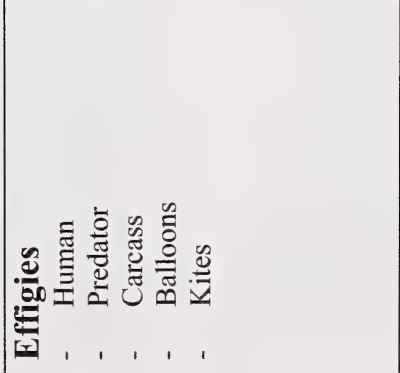 \\
\hline
\end{tabular}




\begin{tabular}{|c|c|c|c|c|}
\hline 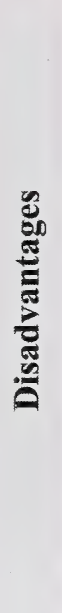 & 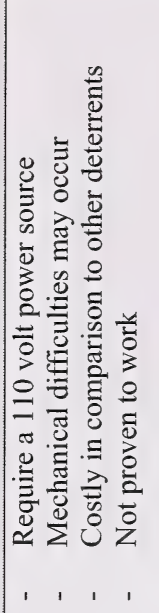 & 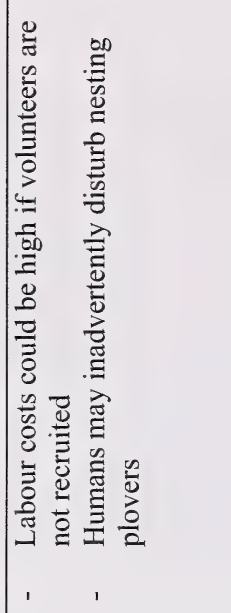 & 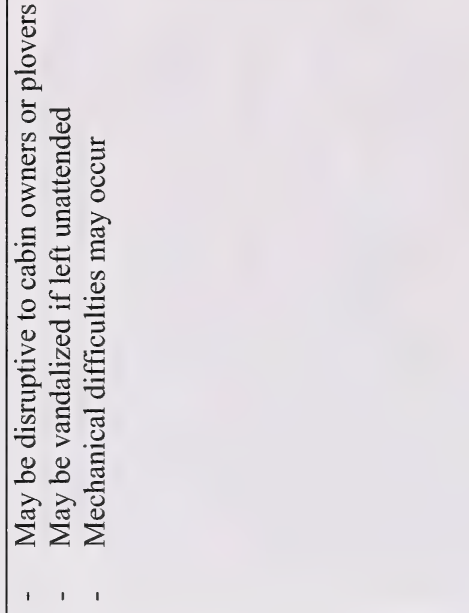 & 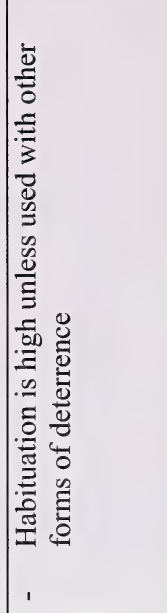 \\
\hline 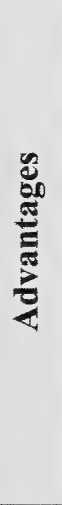 & 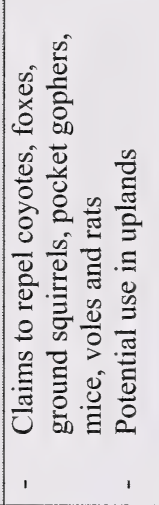 & 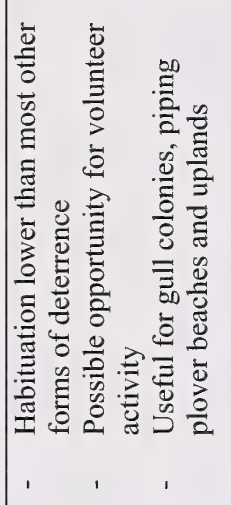 & 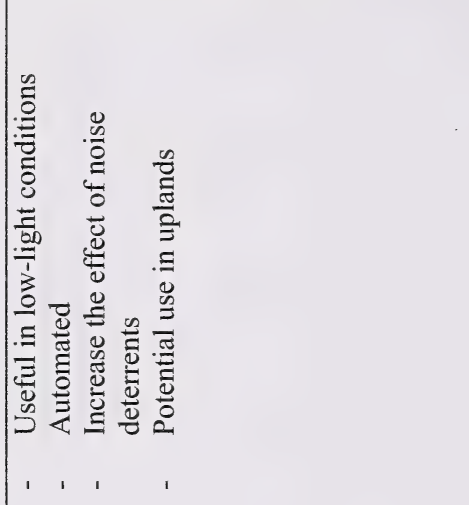 & 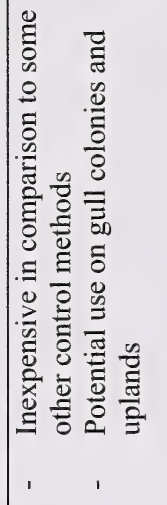 \\
\hline 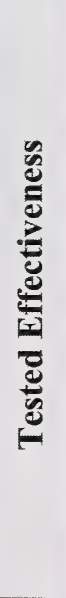 & 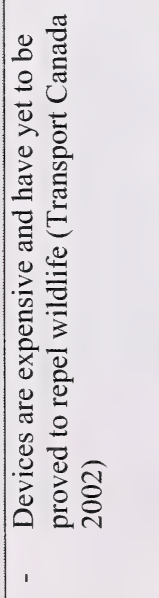 & 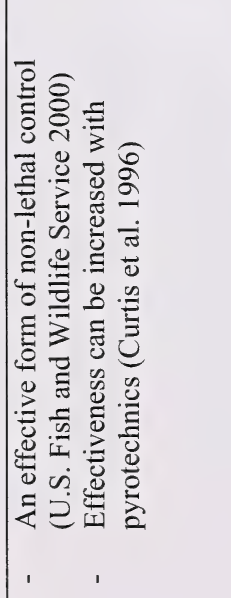 & 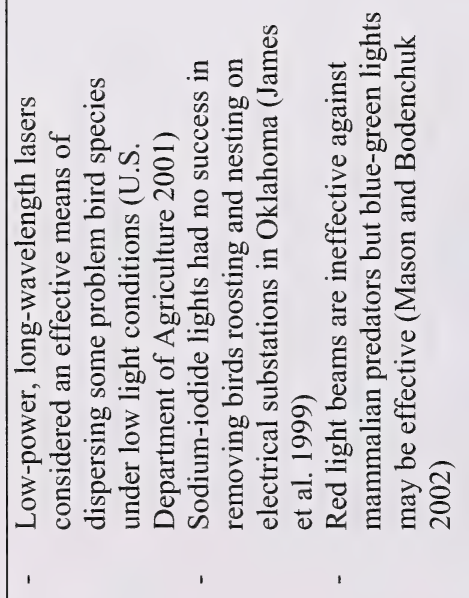 & 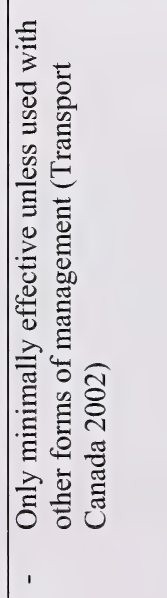 \\
\hline 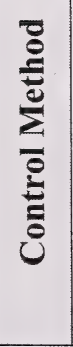 & 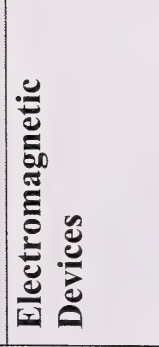 & 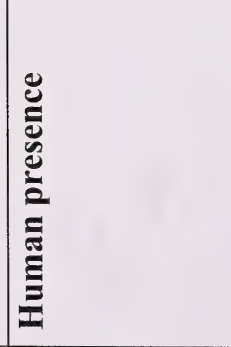 & 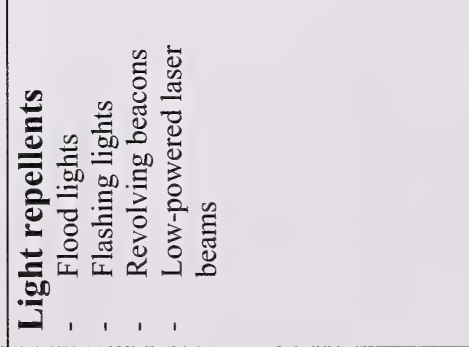 & 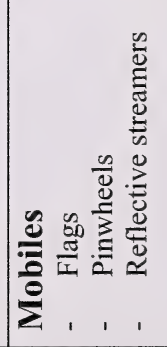 \\
\hline
\end{tabular}




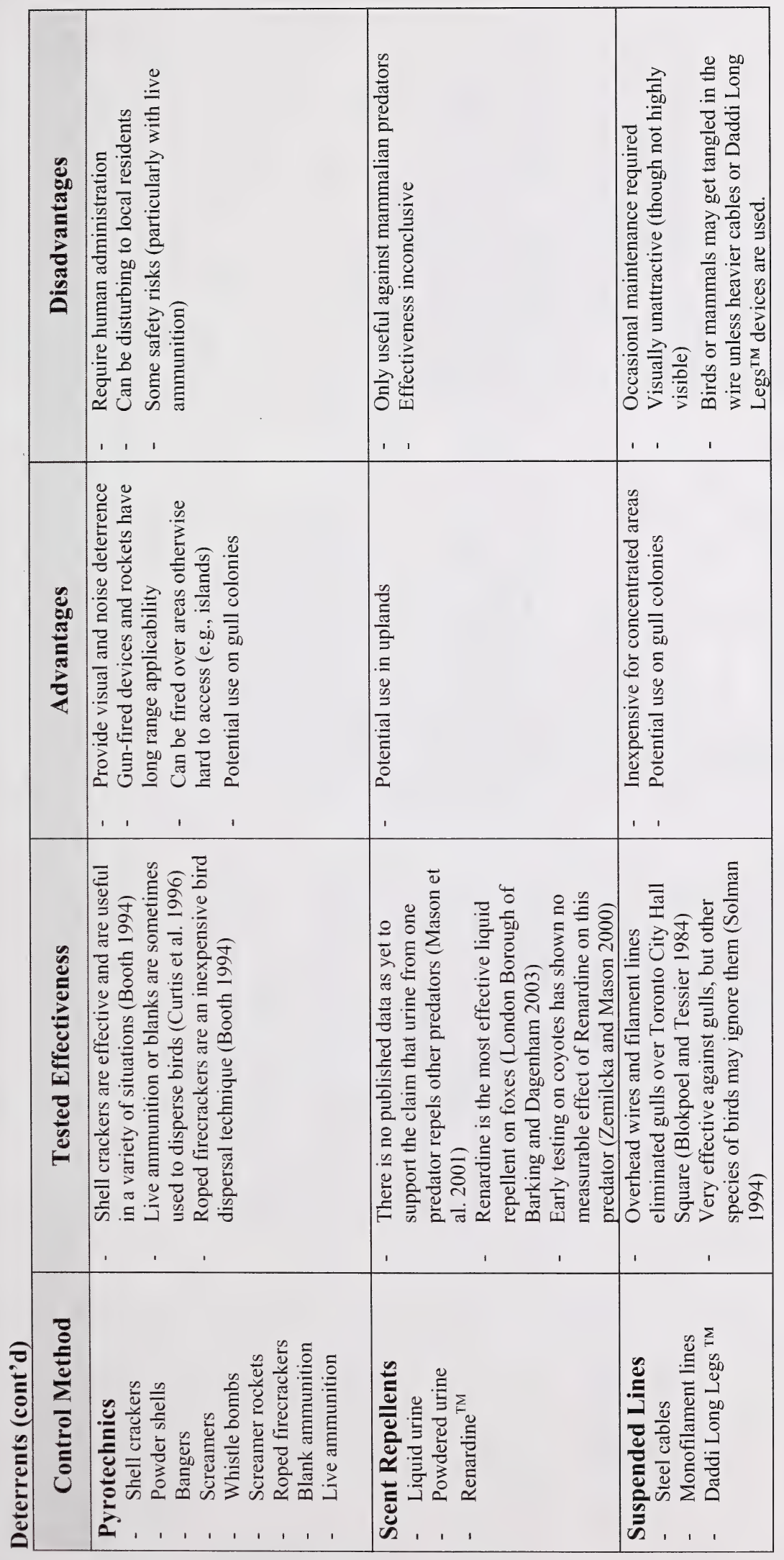




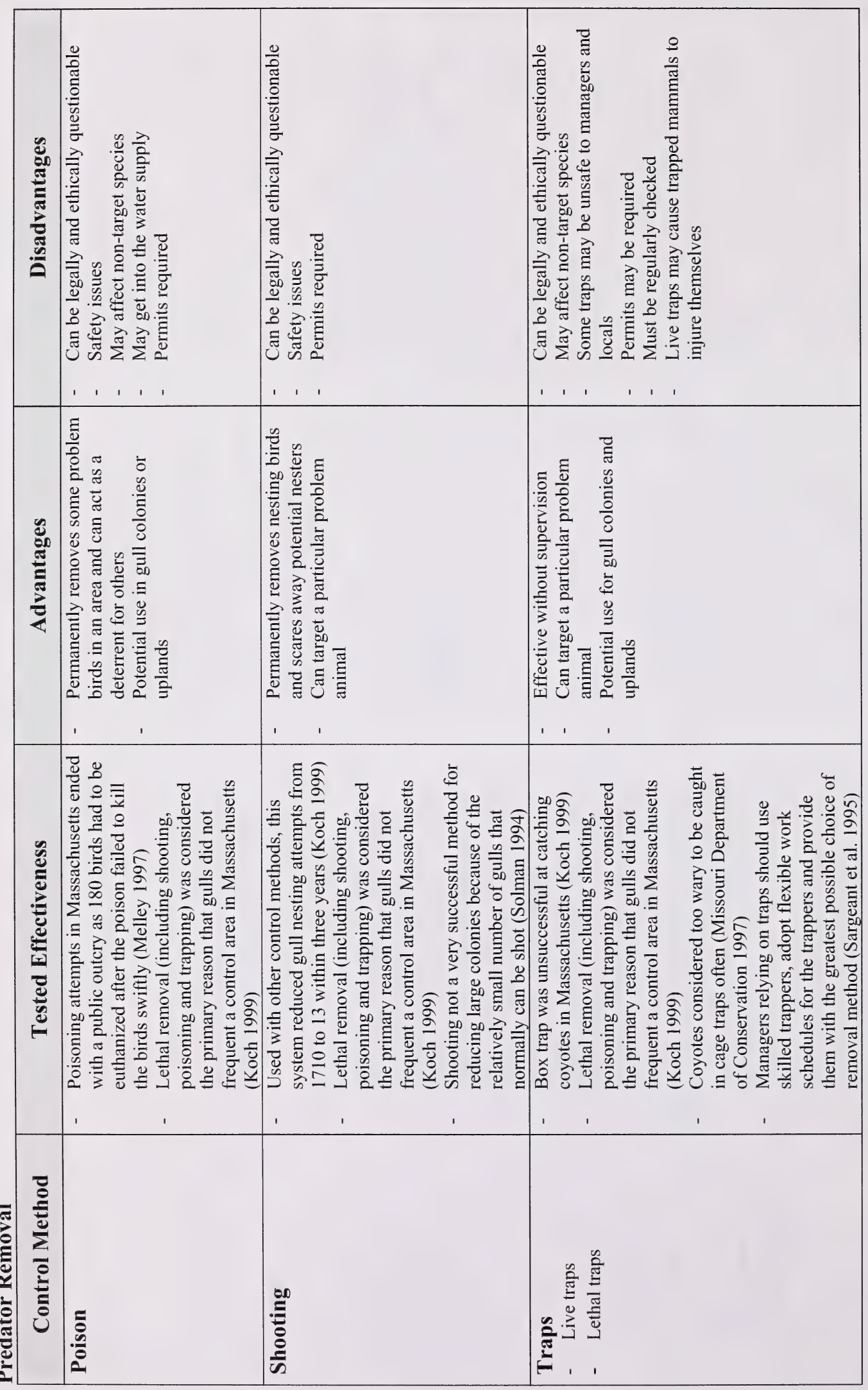




\begin{tabular}{|c|c|c|c|c|c|}
\hline & & 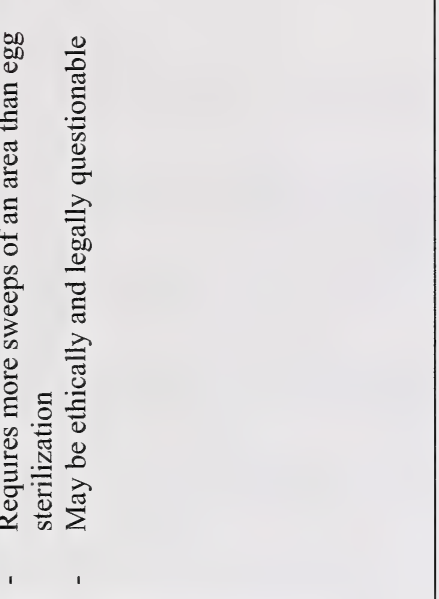 & 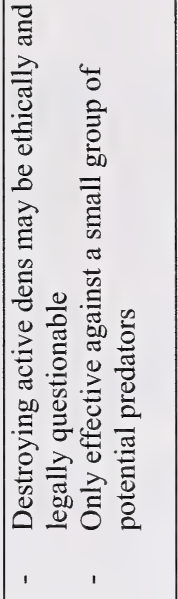 & 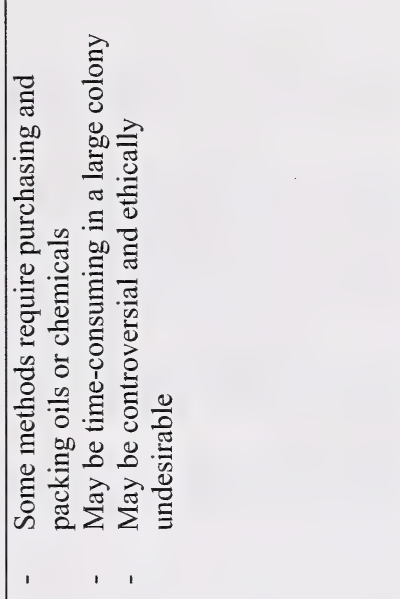 & 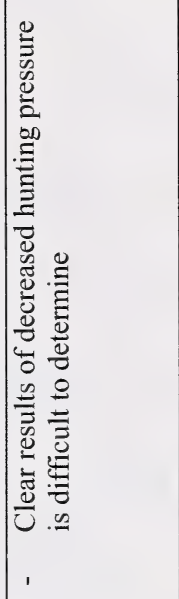 \\
\hline & & 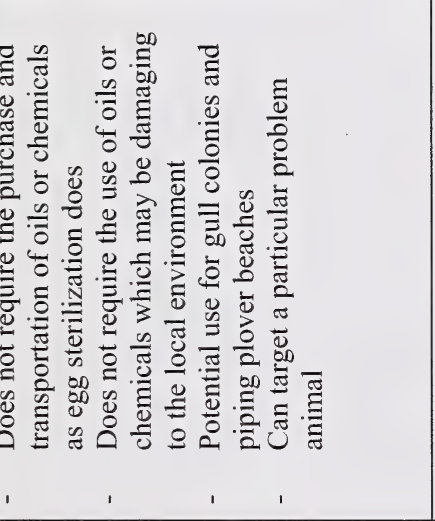 & 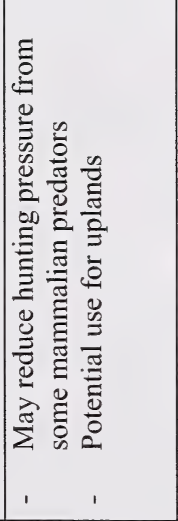 & 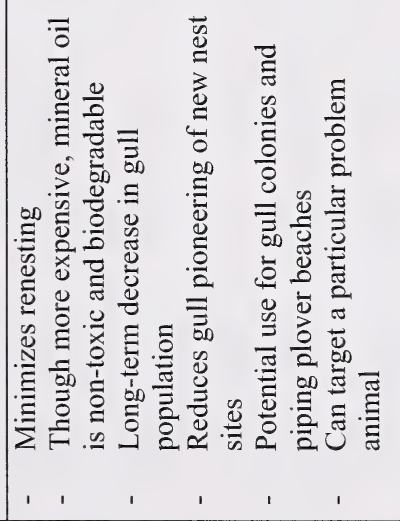 & 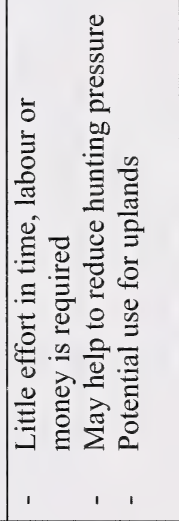 \\
\hline & & 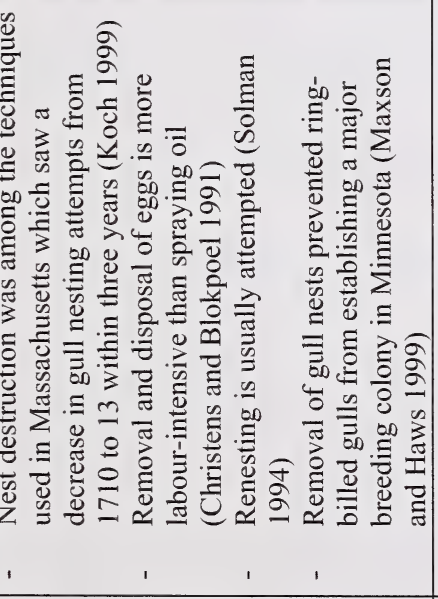 & 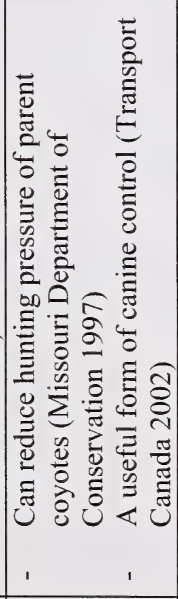 & 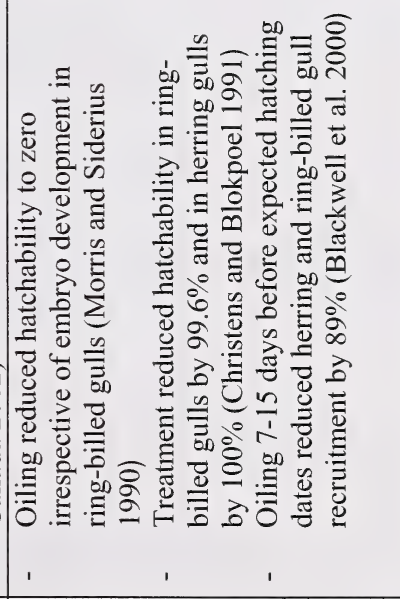 & 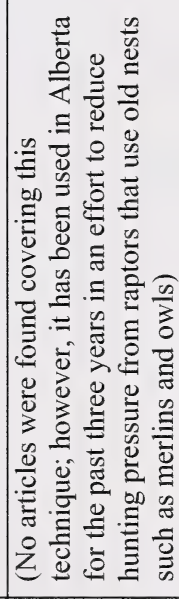 \\
\hline & & 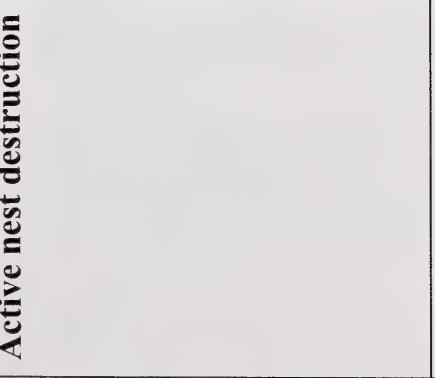 & 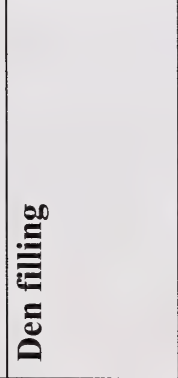 & 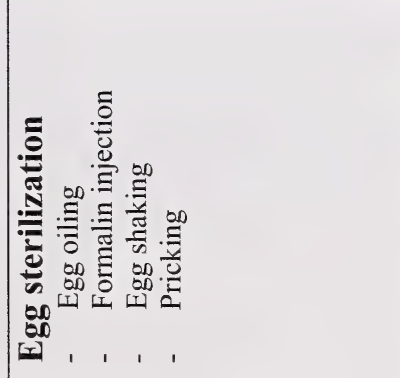 & 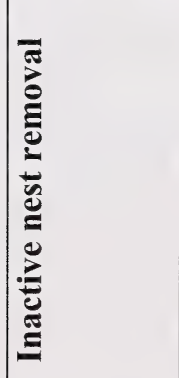 \\
\hline
\end{tabular}




\section{List of Titles in This Series}

(as of March 2004)

No. 1 Alberta species at risk program and projects 2000-2001, by Alberta Sustainable Resource Development, Fish and Wildlife Division. (2001)

No. 2 Survey of the peregrine falcon (Falco peregrinus anatum) in Alberta, by R. Corrigan. (2001)

No. 3 Distribution and relative abundance of the shortjaw cisco (Coregonus zenithicus) in Alberta, by M. Steinhilber and L. Rhude. (2001)

No. 4 Survey of the bats of central and northwestern Alberta, by M.J. Vonhof and D. Hobson. (2001)

No. 52000 survey of the Trumpeter Swan (Cygnus buccinator) in Alberta, by M.L. James and A. James. (2001)

No. 6 2000/2001 Brassy Minnow inventory at Musreau Lake and outlet, by T. Ripley. (2001)

No. 7 Colonial nesting waterbird survey in the Northwest Boreal Region - 2000, by M. Hanneman and M. Heckbert. (2001)

No. 8 Burrowing owl trend block survey and monitoring - Brooks and Hanna areas, by D. Scobie and R. Russell. (2000)

No. 9 Survey of the Lake Sturgeon (Acipenser fulvescens) fishery on the South Saskatchewan River, Alberta (June-September, 2000), by L.A. Winkel. (2000)

No. 10 An evaluation of grizzly bear-human conflict in the Northwest Boreal Region of Alberta (19912000) and potential mitigation, by T. Augustyn. (2001)

No. 11 Harlequin duck monitoring in the Northern East Slopes of Alberta: 1998-2000 preliminary results, by J. Kneteman and A. Hubbs. (2000)

No. 12 Distribution of selected small mammals in Alberta, by L. Engley and M. Norton. (2001)

No. 13 Northern leopard frog reintroduction. Raven River - Year 2 (2000), by K. Kendell. (2001)

No. 14 Cumulative effects of watershed disturbances on fish communities in the Kakwa and Simonette watersheds. The Northern Watershed Project. Study 3 Progress report, by T. Thera and A. Wildeman. (2001)

No. 15 Harlequin duck research in Kananaskis Country in 2000, by C.M. Smith. (2001)

No. 16 Proposed monitoring plan for harlequin ducks in the Bow Region of Alberta, by C.M. Smith. (2001)

No. 17 Distribution and relative abundance of small mammals of the western plains of Alberta as determined from great horned owl pellets, by D. Schowalter. (2001)

No. 18 Western blue flag (Iris missouriensis) in Alberta: a census of naturally occurring populations for 2000 , by R. Ernst. (2000)

No. 19 Assessing chick survival of sage grouse in Canada, by C.L. Aldridge. (2000)

No. 20 Harlequin duck surveys of the Oldman River Basin in 2000, by D. Paton. (2000) 
No. 21 Proposed protocols for inventories of rare plants of the Grassland Natural Region, by C. Wallis. (2001)

No. 22 Utilization of airphoto interpretation to locate prairie rattlesnake (Crotalus viridis viridis) hibernacula in the South Saskatchewan River valley, by J. Nicholson and S. Rose. (2001)

No. 23 2000/2001 Progress report on caribou research in west central Alberta, by T. Szkorupa. (2001)

No. 24 Census of swift fox (Vulpes velox) in Canada and Northern Montana: 2000-2001, by A. Moehrenschlager and C. Moehrenschlager. (2001)

No. 25 Population estimate and habitat associations of the long-billed curlew in Alberta, by E.J. Saunders. (2001)

No. 26 Aerial reconnaissance for piping plover habitat in east-central Alberta, May 2001, by D.R.C. Prescott. (2001)

No. 27 The 2001 international piping plover census in Alberta, by D.R.C. Prescott. (2001)

No. 28 Prairie rattlesnake (Crotalus viridis viridis) monitoring in Alberta - preliminary investigations (2000), by S.L. Rose. (2001)

No. 29 A survey of short-horned lizard (Phrynosoma hernandesi hernandesi) populations in Alberta, by J. James. (2001)

No. 30 Red-sided garter snake (Thamnophis sirtalis parietalis) education and relocation project - final report, by L. Takats. (2002)

No. 31 Alberta furbearer harvest data analysis, by K.G. Poole and G. Mowat. (2001)

No. 32 Measuring wolverine distribution and abundance in Alberta, by G. Mowat. (2001)

No. 33 Woodland caribou (Rangifer tarandus caribou) habitat classification in northeastern Alberta using remote sensing, by G.A. Sanchez-Azofeifa and R. Bechtel. (2001)

No. 34 Peregrine falcon surveys and monitoring in the Parkland Region of Alberta, 2001, by R. Corrigan. (2002)

No. 35 Protocol for monitoring long-toed salamander (Ambystoma macrodactylum) populations in Alberta, by T. Pretzlaw, M. Huynh, L. Takats and L. Wilkinson. (2002)

No. 36 Long-toed salamander (Ambystoma macrodactylum) monitoring study in Alberta: summary report 1998-2001, by M. Huynh, L. Takats and L. Wilkinson. (2002)

No. 37 Mountain plover habitat and population surveys in Alberta, 2001, by C. Wershler and C. Wallis. (2002)

No. 38 A census and recommendations for management for western blue flag (Iris missouriensis) in Alberta, by R. Ernst. (2002)

No. 39 Columbian mountain amphibian surveys, 2001, by D. Paton. (2002)

No. 40 Management and recovery strategies for the Lethbridge population of the prairie rattlesnake, by R. Ernst. (2002) 
No. 41 Western (Aechmophorus occidentalis) and eared (Podiceps nigricollis) grebes of central Alberta: inventory, survey techniques and management concerns, by S. Hanus, H. Wollis and L. Wilkinson. (2002)

No. 42 Northern leopard frog reintroduction - year 3 (2001), by K. Kendell. (2002)

No. 43 Survey protocol for the northern leopard frog, by K. Kendell. (2002)

No. 44 Alberta inventory for the northern leopard frog (2000-2001), by K. Kendell. (2002)

No. 45 Fish species at risk in the Milk and St. Mary drainages, by RL\&L Environmental Services Ltd. (2002)

No. 46 Survey of the loggerhead shrike in the southern aspen parkland region, 2000-2001, by H. Kiliaan and D.R.C. Prescott. (2002)

No. 47 Survey of native grassland butterflies in the Peace parkland region of northwestern Alberta - 2001, by M. Hervieux. (2002)

No. 48 Caribou range recovery in Alberta: 2001/02 pilot year, by T. Szkorupa. (2002)

No. 49 Peace parkland native grassland stewardship program 2001/02, by A. Baker. (2002)

No. 50 Carnivores and corridors in the Crowsnest Pass, by C. Chetkiewicz. (2002)

No. 512001 Burrowing owl trend block survey and monitoring, Brooks and Hanna areas, by D. Scobie. (2002)

No. 52 An evaluation of the ferruginous hawk population in Alberta based on recent trend data, by D.P. Stepnisky, G.L. Erickson, J. Iwaasa and B. Taylor. (2002)

No. 53 Alberta amphibian call surveys. A pilot year. Final report, by L. Takats and C. Priestley. (2002)

No. 54 Utilization of a roadside survey technique to survey burrowing owl (Athene cunicularia hypugaea) in southeastern Alberta, by J. Nicholson and C. Skiftun. (2002)

No. 55 Alberta species at risk program and projects 2001-2002, by Alberta Sustainable Resource Development, Fish and Wildlife Division. (2002)

No. 56 Developing a habitat-based population viability model for greater sage-grouse in southeastern Alberta, by C.L. Aldridge. (2001)

No. 57 Peregrine falcon surveys and monitoring in the Northeast Boreal Region of Alberta, 2001, by R. Corrigan. (2002)

No. 582002 burrowing owl trend block survey and monitoring, Brooks area, by R.F. Russell. (2002)

No. 59 Rare plant inventory of the eastern edge of the lower foothills natural subregion, west-central Alberta, by J. Doubt. (2002)

No. 60 Western (Aechmophorus occidentalis) and eared (Podiceps nigricollis) grebes of central Alberta: 2002 field summary, by S. Hanus, L. Wilkinson and H. Wollis. (2002)

No. 61 Inventory of western spiderwort (Tradescantia occidentalis) in Alberta: 2002, by S. Peters. (2003) 
No. 62 Bullsnakes (Pituophis catenifer sayi) in Alberta: literature review and data compilation, by K.J. Kissner and J. Nicholson. (2003)

No. 63 Distribution of Ord's kangaroo rats in southeastern Alberta, by D.L. Gummer and S.E. Robertson. (2003)

No. 64 Lethbridge prairie rattlesnake conservation project: 2002/2003 progress report, by R.D. Ernst. (2003)

No. 65 Short-horned lizard (Phrynosoma hernandesi hernandesi) populations in Alberta - 2002 survey results, by J.D. James. (2003)

No. 66 Inventory and monitoring protocol for naturally occurring western blue flag (Iris missouriensis) in Alberta, by R.D. Ernst. (2003)

No. 67 The use of call playbacks for censusing loggerhead shrikes in southern Alberta, by D.R.C. Prescott. (2003)

No. 68 Survey of bats in northeastern Alberta, by A. Hubbs and T. Schowalter. (2003)

No. 69 Survey protocol for the Richardson's ground squirrel, by B.A. Downey. (2003)

No. 70 Population estimates and a survey protocol for ferruginous hawks in Alberta, by B.N. Taylor. (2003)

No. 71 Testing methods for detecting wolverine, by G. Mowat, C. Kyle and D. Paetkau. (2003)

No. 72 A multi-species conservation strategy for species at risk in the Milk River basin: year 1 progress report, by R.W. Quinlan, B.A. Downey, B.N. Taylor, P.F. Jones and T.B. Clayton. (2003)

No. 73 Long-toed salamander (Ambystoma macrodactylum) conservation in the Alberta foothills: 2002 field summary report, by L. Wilkinson and S. Hanus. (2003)

No. 74 Researching Amphibian Numbers in Alberta (RANA): 2002 provincial summary, by L. Wilkinson and S. Hanus. (2003)

No. 75 Distribution and habitat associations of the long-toed salamander (Ambystoma macrodactylum) in the Oldman River drainage, by K. Pearson. (2003)

No. 76 Prairie rattlesnake (Crotalus viridis) hibernacula: monitoring history in Alberta 1987-2002, by K.J. Kissner and J. Nicholson. (2003)

No. 77 Alberta species at risk program and projects 2002-2003, by Alberta Sustainable Resource Development, Fish and Wildlife Division. (2003)

No. 78 Northern leopard frog reintroduction: Year 4 (2002), by K. Kendell. (2003)

No. 79 Magrath Northern Leopard Frog Reintroduction Project - Year 1 Progress Report, by K.A. Romanchuck. (2003)

No. 80 Conservation Overview of Butterflies in the Southern Headwaters at Risk Project (SHARP) Area, by N. Kondla. (2004)

No. 81 Lethbridge Rattlesnake Conservation Project: 2003 Progress Report, by R. Ernst. (2004)

No. 82 Shortjaw Cisco Species at Risk Assessment 2001, by M. Steinhilber. (2004) 
No. 83 Researching Amphibian Numbers in Alberta (RANA): 2003 provincial summary, by L. Wilkinson and K. Kempin. (2004)

No. 84 Methods for Controlling Depredation on Piping Plovers in Alberta: A Literature Review and Synthesis, by R. Schmelzeisen, D.R.C. Prescott and L. Engley. (2004) 



NATIONAL LIBRARY OF CANADA
Bibliothèque nationale du Canada

33286530267331 